\title{
Should Indirect Brokerage Fees Be Capped? Lessons from Mutual Fund Marketing and Distribution Expenses
}

\author{
Natalie Y. Oh, Jerry T. Parwada, and Eric K. M. Tan*
}

\begin{abstract}
Theory predicts that capping brokers' compensation exacerbates the exploitation of retail investors. We show that regulated caps on mutual fund $12 \mathrm{~b}-1$ fees, effectively sales commissions, are associated with negative equity fund performance, but only after a structural shift toward maximum permitted levels of the fees around 2000. Past this break point, flow-performance sensitivity shifts from the middle- to the highest-performing funds, suggesting that the fee cap increases performance-chasing behavior by constraining brokers' incentives to learn about lower-ranked funds. The policy implication is that regulators must reevaluate the efficacy of caps on brokerage fees.
\end{abstract}

\section{Introduction}

The nascent literature on the marketing and distribution of mutual funds finds that broker-sold funds underperform relative to directly sold products (Bergstresser, Chalmers, and Tufano (2009), Del Guercio and Reuters (2014)). There is growing interest in understanding the sources of this apparent conflict of interest. Christoffersen, Evans, and Musto (2013) find that kickbacks made to intermediaries between investors and mutual fund managers through indirect commissions skew brokers' incentives, in that the payments, particularly from sales loads, predict worse performance. Del Guercio and Reuters attribute the continued demand for actively managed mutual funds that underperform passively managed index funds to market segmentation: Direct sold funds attract alpha-chasing investors, whereas funds sold through brokers face weaker incentives to generate alpha. Del Guercio and Reuters attribute the latter effect to Gruber (1996), who

*Oh, natalie.oh@unsw.edu.au, Parwada (corresponding author), j.parwada@unsw.edu.au, School of Banking and Finance, University of New South Wales; Tan, eric.tan@otago.ac.nz, Otago Business School, University of Otago. The authors thank Vikas Agarwal, Dumitrescu Ariadna, Karen Benson, Stephen Brown (the editor), Kingsley Fong, Fabian Irek, Ron Masulis, Stefan Ruenzi, Charles Trzcinka (the referee), and seminar participants at the 2010 European Financial Management Association Meeting, the 2011 Financial Management Association European Conference, and the 2011 Asian Finance Association Meeting for helpful comments. 
highlighted the existence of "disadvantaged" mutual fund investors. This paper contributes to the debate about commission-motivated mutual fund advisors by showing that the regulation of sales-related compensation to brokers adversely affects their incentives in choosing appropriate fund products on behalf of investors.

We target mutual fund marketing and distribution expenses (also known as $12 \mathrm{~b}-1$ fees), since the primary use of revenues raised through such fees is now to create incentives for brokers who distribute the vast majority of mutual funds (Christoffersen et al. (2013)). Our study is motivated by recent theories of indirect payments to brokers in financial services. Stoughton, Wu, and Zechner (2011) and Inderst and Ottaviani (2012a) show that, contingent on the existence of savvy investors in the market, commissions alone do not necessarily imply skewed incentives; the producers of financial products will pay commissions to brokers to incentivize the latter to learn about products that are most suitable for their heterogeneous customers. Naïve customers who trust biased advice will be exploited by being charged higher prices for low-quality products. In Inderst and Ottaviani's (2012a) model, savvy investors are aware that some advisors possess private information about the suitability of a fund firm's products, and the disclosure required by regulators is clear enough to inform the investors on brokers' incentives and to subsequently allow them to infer the quality of the fund. ${ }^{1}$ Inderst and Ottaviani show that policy interventions to prohibit or cap indirect payments exacerbate brokers' skewed incentives by removing the incentive of intermediaries to learn about the quality of financial products, thereby reducing the overall quality of advice. ${ }^{2}$ Intuitively, the unintended consequences of capping indirect brokerage fees are more severe for complex and specialized products that demand brokers to be better informed.

The U.S. mutual fund industry has the key ingredients necessary to test the predictions of Inderst and Ottaviani's (2012a) theory concerning the unintended consequences of policy interventions in indirect brokerage fee payments: brokerage fee caps and the significant presence of uninformed investors. First, under the rules of the Financial Industry Regulatory Authority (FINRA), formerly the National Association of Security Dealers (NASD), since 1993, the 12b-1 fee has been capped at $1 \%(0.25 \%)$ of load (no-load) mutual funds' assets annually. Second, a large proportion of the U.S. population invests in mutual funds: $44 \%$ of U.S. households, or 53.8 million households, as of 2012. Most such households have incomes of less than $\$ 100,000$, with a median of $\$ 80,000$ (Investment Company Institute (ICI) (2013)). ${ }^{3}$ A U.S. Securities and Exchange Commission (SEC)

\footnotetext{
${ }^{1}$ Inderst and Ottaviani (2012a) show that a binding cap reduces efficiency under the assumption that firms are asymmetric in terms of their cost efficiency.

${ }^{2}$ Policy interventions that mandate disclosure may protect naïve investors and improve their welfare. Critically, the producers of financial products continue to rely on exploiting naïve clients. Competition attenuates these negative effects, but profit-maximizing financial product providers have limited incentives to educate naïve investors.

${ }^{3}$ In comparison, as of 1980 , less than $6 \%$ of U.S. households owned mutual funds (ICI (2013)).
} 
study concludes that retail investors "lack basic financial literacy." 4 This institutional setting has attributes that Inderst and Ottaviani (2012a) identify as potential causes of unintended negative consequences of regulation.

We hypothesize that the existence of regulated caps on 12b-1 fees exacerbates conflicts of interest that encourage mutual fund brokers to sell underperforming funds. Our main identification strategy is centered on the fact that, with regulated caps, some funds charge $12 \mathrm{~b}-1$ fees at or close to the maximum permissible, while others compete below the cap. The economics literature on price caps (e.g., Knittel and Stango (2003)) tells us that it is extremely difficult for regulators to set the caps at competitive equilibrium levels and that price setters may charge below the cap while others move toward the cap. We conjecture that if the costs of researching fund products rise over time, the industry may shift toward regulated caps, at which point caps begin to have the detrimental effects contemplated by Inderst and Ottaviani (2012a), as shown by an overall decline in the quality of advice.

Since charging 12b-1 fees toward the regulated cap is endogenous to brokers' search and other costs, it is interesting to observe the fee-setting behavior of fund families relative to the maximum permitted levels. In Figure 1, we depict a dramatic rise of $12 \mathrm{~b}-1$ fees over the early part of our sample period, which accelerates even more from 1998 onward, before apparent stability is established from about 2001 onward. Our data show that, between 1993 and 2000, in both load and no-load funds, the brokerage fees levied on client assets increase by up to $70 \%$. Formal structural break tests indicate 2000 as the year in which a structural break occurs in the number of equity funds charging $12 \mathrm{~b}-1$ fees at the regulated cap. Therefore, in a series of analyses before and after 2000, we test our first hypothesis that charging $12 \mathrm{~b}-1$ fees at the cap is related to brokers' recommendations of underperforming equity funds.

We also directly test for evidence that the misselling of equity funds is associated with limits imposed by regulated caps on brokers' incentives to learn about the quality of the funds they sell to investors. Abstracting from the theoretical work of Huang, Wei, and Yan (2007), we form our second hypothesis. We expect that, without caps, funds would pay brokers higher compensation, commensurate with the cost of learning about the quality of the funds they market. Because of the caps, however, brokers' incentives promote performance-chasing behavior instead of informed advice. This hypothesis is backed by developments in the mutual fund industry suggesting that the structural break in marketing and distribution expenses toward the regulated cap occurred because of increased costs of researching equity funds. For example, the year 2000 is immediately after competitive maturity was established in the mutual fund market (Wahal and Wang (2011)). With the proliferation of fund products that this shift induced, it is reasonable to expect that searching for good funds became more difficult. In addition, Regulation Fair Disclosure (Reg FD) was introduced in 2000, effectively curtailing the preferential access of mutual funds to nonpublic information about equities

\footnotetext{
${ }^{4}$ See Office of Investor Education and Advocacy, SEC, Staff Study Regarding Financial Literacy among Investors (2012), available at http://www.sec.gov/news/studies/2012/917-financial-literacystudy-part1.pdf.
} 
FIGURE 1

Level of 12b-1 Fees for Load and No-Load Funds

Figure 1 plots the average 12B-1_FEE and the proportion of funds charging $12 \mathrm{~b}-1$ fees at the cap $(\mathrm{CAP}=1)$ for both load and no-load equity funds. The sample period is from 1993 to 2012. Load funds are funds that levy investors' entry (front-end) or exit (back-end) fees or $12 \mathrm{~b}-1$ fees greater than $0.25 \%$, while no-load funds are funds that do not charge any loads or a $12 \mathrm{~b}-1$ fee exceeding $0.25 \%$.
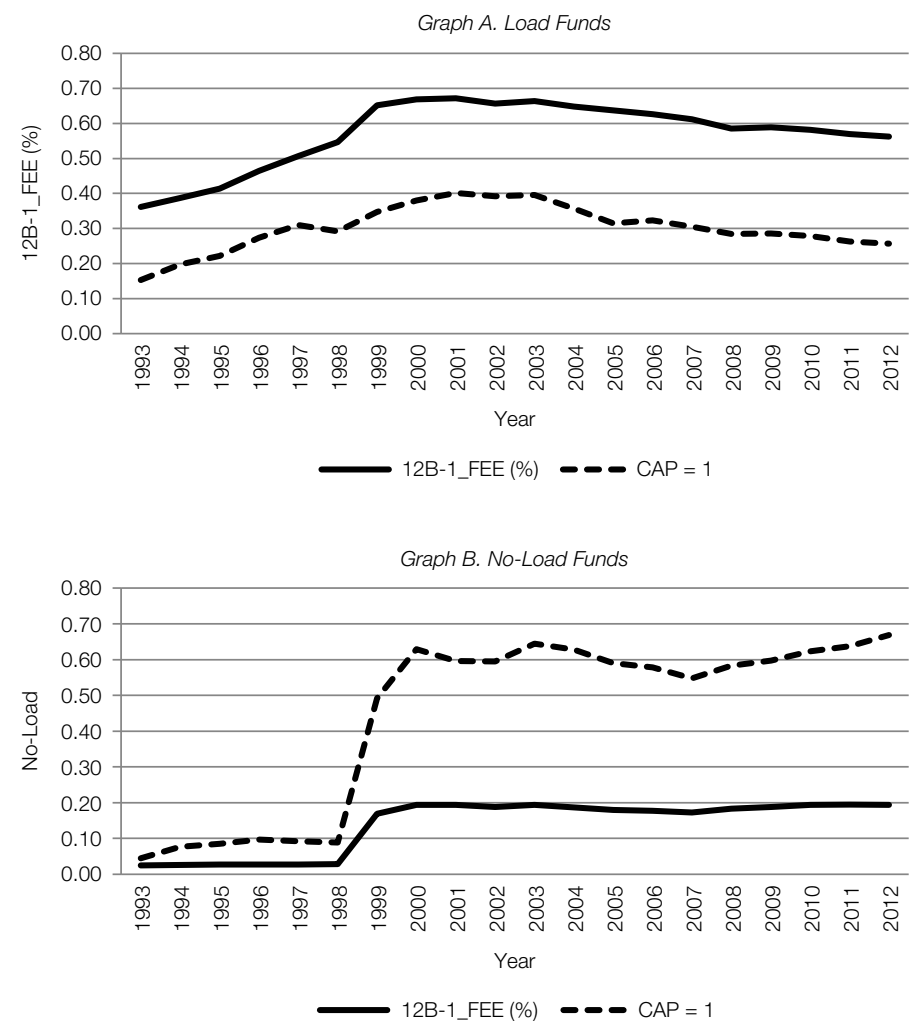

and, with it, fund performance (Bhojraj, Cho, and Yehuda (2012)). It is likely that these combined developments have made it difficult for mutual fund brokers to differentiate between fund products based on performance.

The U.S. mutual fund industry also has characteristics that provide plausible counterfactuals to our main hypotheses. First, in the theory of Inderst and Ottaviani (2012a), the unintended consequences of imposing caps on advisors' indirect fees are counteracted by mandated disclosure. Disclosure around mutual fund distribution and selling is heavily regulated. Christoffersen et al. (2013) carefully document how reporting on payments to sales agents through N-SAR (Form N Semi-Annual Report) semiannual and annual filings by registered investment companies to the SEC has been mandatory in varying formats since the 1960s.

Second, the negative effects of banning or capping indirect brokerage payments can also be countered by the existence of informed investors in the market (Inderst and Ottaviani (2012a)). We provide evidence of the increasing participation of institutional investors in the mutual fund industry in Figure 2. Evans and 
FIGURE 2

Market Share of Retail, Institutional, and Mixed Share Classes over Time

Figure 2 shows the stacked totals of U.S. equity funds classified according to their share classes from 1993 to 2012. Specialist institutional and specialist retail funds have share classes that serve only institutional and retail investors, respectively. Mixed class funds serve both institutional and retail investors. Source: CRSP Mutual Fund Database.

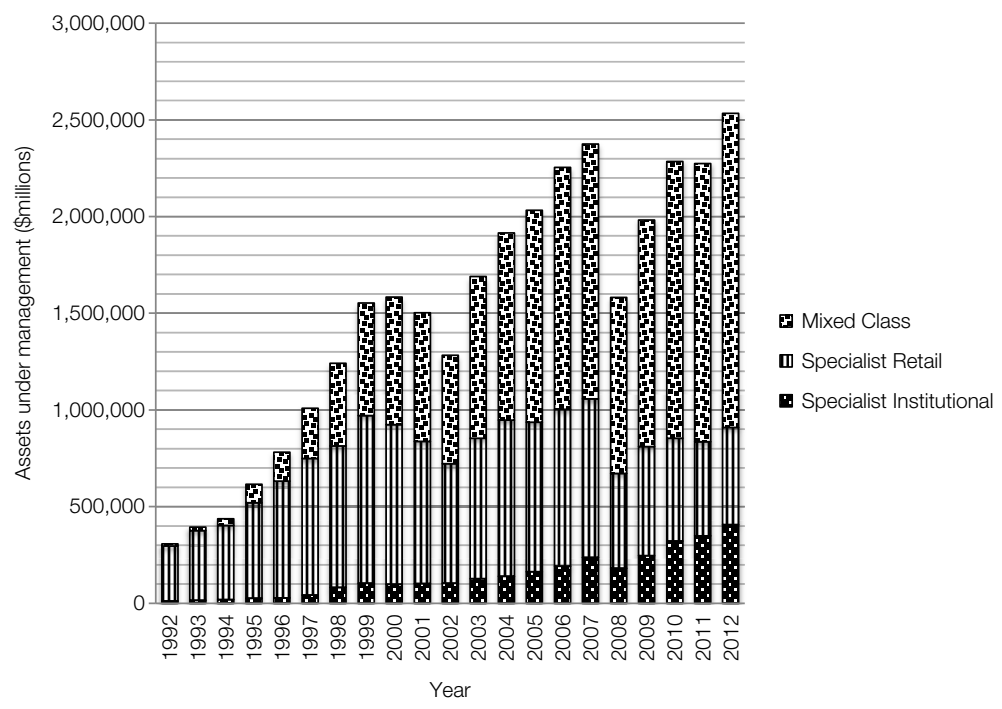

Fahlenbrach (2012) demonstrate that in fund families that cater to institutional investors, the welfare of retail investors in closely related funds is significantly improved. In addition, the participation of high-net-worth individuals in the mutual fund industry is increasing (ICI (2013)).

Third, competition can also reduce exploitation (Inderst and Ottaviani (2012a)). Wahal and Wang (2011) show that the U.S. mutual fund industry became competitive in the late 1990s, marked by an exponential increase in the number of fund companies and mutual fund products. It is possible that these 3 factors constitute sufficiently countervailing conditions to make the capped $12 \mathrm{~b}-1$ fee regime effective, at least in the relationships brokers have with their clients. In such a case, we would not observe our hypothesized effects.

Concentrating on the structural shift toward maximum permitted levels of 12b-1 fees, the results of our analyses are supportive of Inderst and Ottaviani's (2012a) theory and may be summarized as follows. Consistent with our first hypothesis, we provide new evidence that the association of mutual fund brokerage fees with underperforming fund products is reflected in the data for funds that charge higher brokerage fees only after 2000. Specifically, we trace negative performance persistence mostly to funds that charge $12 \mathrm{~b}-1$ fees at the cap in the post2000 period. We also show that the amount of marketing and distribution expenses charged by the funds predicts negative fund performance after 2000 . Thus, our paper reports a unique finding that the Bergstresser et al. (2009) and Del Guercio and Reuters (2014) results are confined to the post-2000 period, which also comprises 
the years of increased 12b-1 expenses and more funds at the maximum allowed 12b-1 expense.

Further, we report results in support of our second hypothesis, that $12 \mathrm{~b}-1$ fee caps affect mutual fund brokers' learning incentives. Adopting the empirical framework of Huang et al. (2007), we show that the sensitivity of mutual fund flows to performance has shifted from the mid- to the high-performance category. Huang et al. (2007) demonstrate theoretically that, for investors (and their advisors, in our case), mutual fund search and learning costs form a hurdle that they have to clear first based on information they have on past fund performance before considering the fund for purchase. The result of this vetting mechanism is to shift performance sensitivity away from funds with low past performance to those with medium levels of past returns. Thus, we show another unique finding that Huang et al.'s result holds only for the pre-2000 period; thereafter, performance sensitivity shifts exclusively to funds with high past performance. This result suggests that the fund search hurdle shifts past the compensation permitted by fund brokers under the $12 \mathrm{~b}-1$ cap regime, in line with our hypothesis that the capping of marketing and distribution expenses curtails fund advisors' incentives to learn about the products they sell to investors. Moreover, we show that there are net outflows from funds with greater 12b-1 expenditures in the high-performance categories, suggesting that brokers are even resorting to "churning" clients, regardless of past fund performance, possibly to chase revenues. Taken together, our findings are consistent with the theoretical predictions of Inderst and Ottaviani (2012a).

Apart from contributing to the sparse literature on mutual fund brokerage, our findings have policy implications. As discussed in detail below, whether indirect commissions should be capped is the subject of ongoing debate among mutual fund industry regulators in the United States and elsewhere. Since 2010, for example, the SEC has been considering removing caps from $12 \mathrm{~b}-1$ fees and allowing mutual fund brokers to directly charge their clients for the actual expenses incurred on researching fund products. In contrast, European regulators seem to favor caps on indirect fund sales fees. The evidence we present in this paper suggests there is merit in the SEC's argument. Furthermore, our findings may inform regulators on the effectiveness of brokerage fee arrangements similar to $12 \mathrm{~b}-1$ fees. For example, the much larger $8.5 \%$ sales load on mutual funds is also capped but subject to minimum investment and holding period thresholds, among other rebate conditions. Because these additional details are not provided in standard databases, we leave the study of sales loads to future research as data become available.

The rest of this paper is organized as follows: Section II provides the relevant background and develops the main hypotheses. We discuss our data and key variables in Section III, and we present the methods and empirical results in Section IV. In Section V, we put forth our robustness tests. Section VI concludes the paper.

\section{Background and Hypotheses}

\section{A. Regulation of $12 b-1$ Fees}

The SEC regulates mutual fund families' indirect payments to brokers in the form of the so-called $12 \mathrm{~b}-1$ fee that funds levy on investors' assets under 
management (AUM) to cover marketing and distribution expenses. ${ }^{5}$ This fee has effectively become an indirect sales fee paid out of mutual fund assets to brokers. The majority (63\%) of 12b-1 fees are used to compensate brokers for initial sales (Mahoney (2004)). Almost the entire remainder of the fee also goes to brokers for "ongoing shareholder services," leaving only $2 \%$ for advertising (ICI (2011)).

FINRA has long regarded front-end loads and 12b-1 fees as different forms of the same thing: sales loads. For example, in 1993, the NASD issued a rule barring brokers or their firms from representing a mutual fund as "no load" or as having "no sales charge" if the fund imposes a front-end load, a redemption fee, or a $12 b-1$ fee exceeding $0.25 \%$ of average net assets per year. ${ }^{6}$

Marketing and distribution fees have long been capped by regulation. On July 7, 1993, the SEC approved changes in the NASD rules governing investment company sales charges. ${ }^{7}$ These amendments place an annual cap on $12 \mathrm{~b}-1$ fees of 75 basis points (bps), with an additional annual service fee of $25 \mathrm{bps}$, hence, a combined $12 \mathrm{~b}-1$ fee of $1 \%$ for load funds and $0.25 \%$ for no-load funds. The introduction of a regulated cap gives us sufficient variability in our analysis, because, as we show below, some funds choose to charge $12 \mathrm{~b}-1$ fees at the regulated cap while others impose lower levels.

The U.S. mutual fund industry has experienced a marked decline in load fees paid by investors and a shift toward asset-based fees, such as $12 \mathrm{~b}-1$ fees. For example, the average front-end load fees that investors actually paid have declined significantly, from nearly $4 \%$ in 1990 to $1 \%$ or less in 2012 (ICI (2013)). During the same time period, in addition, $12 \mathrm{~b}-1$ fees paid by investors have increased by nearly 10 -fold, from $\$ 1.1$ billion in 1990 to $\$ 10.6$ billion in 2010 (ICI (2011)). ${ }^{8}$ Overall, in our sample period, brokers appear to have been increasingly compensated indirectly from asset-based fees through a fund's $12 \mathrm{~b}-1$ fee rather than directly through load fees.

Regulators are concerned about the effectiveness of the indirect brokerage fee regime. The Dodd-Frank Wall Street Reform and Consumer Protection Act of 2010 gives the SEC broad powers to establish wide-ranging rules to regulate the standard of conduct of broker-dealers in relation to retail customers. On brokers' compensation and incentives, the SEC has unanimously voted to recommend further changes to the regulation and disclosure of fund fees. ${ }^{9}$ Former SEC Chair Mary Schapiro summarizes the regulator's concerns about the usage of 12b-1 fees: $:^{10}$

${ }^{5}$ The term 12b-1 fees is in reference to the Investment Company Act of 1940's Rule 12b-1, which was adopted by the SEC in Oct. 1980 to allow for a mutual fund's own assets to be used to pay distribution charges such as marketing and distribution expenses.

${ }^{6}$ See NASD conduct rule 2830(d)(4).

${ }^{7}$ See Release No. 34-33673; File No. SR-NASD-93-42, Federal Register Vol. 59, No. 42 (Mar. 3, 1994).

${ }^{8}$ Information regarding the level of $12 \mathrm{~b}-1$ fees paid by investors is not available, however, in ICI Reports from 2012 onwards.

${ }^{9}$ See Mutual Fund Distribution Fees; Confirmations, SEC Release Nos. 33-9128; 34-62544; IC29367 (July 21, 2010). As of the beginning of 2015, these proposals had not yet been implemented.

${ }^{10}$ Available at http://www.sec.gov/news/speech/2010/spch072110mls-12b1.htm. 
Rule $12 \mathrm{~b}-1$ was borne of a period in the late 1970 s when funds were losing investor assets faster than they were attracting new assets. And, self-distributed funds were emerging, in search of ways to pay for necessary marketing expenses.

At the time, it was thought that investors would benefit if a fund could "grow" by using some of its own assets to market itself and make distribution payments. This, it was believed, would result in improved economies of scale and, ultimately, lower expenses.

The imposition of 12b-1 fees, however, has been anything but shortterm. In fact, very quickly these fees evolved from payment for advertising and marketing to an alternate form of compensation, or sales load, paid to intermediaries selling fund shares. In addition, $12 \mathrm{~b}-1$ fees compensate broker-dealers and other fund intermediaries for ongoing marketing and related services including recordkeeping, transfer agency services, and overall investor education and consultation.

Schapiro goes on to explain that the main SEC proposal is based on removing caps on sales-related charges:

It also would eliminate the so-called "hidden sales charges" that $12 b-1$ fees can represent by, for the first time, disclosing and regulating these fees as sales charges. And, it would enable broker-dealers to compete for investors by charging mutual fund sales loads at rates they set themselves, rather than at a uniform fee set by the fund. ${ }^{11}$

Despite the occurrence of price caps in financial markets, considerable equivocation remains among regulators regarding the practice. For example, the United Kingdom's Financial Services Authority (FSA) ((2011), p. 55) admits the complexity of the issue in relation to its recent threat to impose fee caps:

The numerous difficulties with setting appropriate price caps are well known. It is a challenging and complex task for regulators in markets that feature natural monopolies and homogeneous products, such as utility markets. In the diverse and ever-changing financial services markets, we consider that the challenges will be even more significant. It is also a blunt tool that may have unintended effects on the market, reducing desirable innovation or leading to all prices rising to the limit we set. Or, firms may simply recover lost revenue by increasing the price of other products.

At the same time, in response to repeated managed fund misselling scandals in the United Kingdom, the FSA has contemplated moving away from a disclosure-centered system of regulating pricing in financial markets to a more interventionist model, which may include imposing fee caps to protect consumers from excessive charges (FSA (2011)). The results of our paper may contribute to a resolution of these debates among regulators.

\footnotetext{
${ }^{11}$ By the end of 2014, the SEC had not acted on these proposals.
} 


\section{B. Background Literature and Hypotheses}

The theoretical literature on indirect fee payments to intermediaries by the producers of financial products is generally sparse. Papers by Stoughton et al. (2011) and Inderst and Ottaviani (2012a) show that kickbacks or indirect payments to financial advisors, such as $12 \mathrm{~b}-1$ fees, are used either to price discriminate in a market that also has sophisticated investors or for aggressive marketing to uninformed market participants. Stoughton et al.'s model makes predictions that are consistent with the findings of the mutual fund brokerage literature, including that fund companies can sell underperforming funds through brokered channels (Bergstresser et al. (2009), Del Guercio and Reuters (2014)). An untested prediction made by Stoughton et al. that we rely on partly to interpret our results (see Section IV) is that the incentives of fund managers to pay kickbacks to intermediaries increase in the fraction of large investors in the market.

Inderst and Ottaviani (2009), (2012a), and (2012b) examine the distorted incentives that arise from, on the one hand, the fact that indirect fees may incentivize paid brokers to learn about which products are appropriate for their heterogeneous investors and, on the other hand, the pressure on the brokers to sell, regardless of quality. We follow Inderst and Ottaviani (2012a). Price discrimination can exist in the Inderst-Ottaviani (2012a) world, as in that of Stoughton et al. (2011), such that naïve customers can be exploited through highly compensated intermediaries. The point of departure of the former from the latter is that Inderst and Ottaviani (2012a) formalize the role of policy interventions, such as the abolishment or capping of indirect fees. Such actions may reverse the intended benefits of policy interventions in a market that contains a mixture of naïve and informed investors, in that an incentive for brokers to invest in learning about products for the benefit of savvy clients is removed, reducing the overall quality of advice. Mandating disclosure may reduce these negative side effects by educating naïve investors into becoming informed clients. However, this is also the very reason financial product producers could resist educating clients.

The empirical literature on $12 \mathrm{~b}-1$ fees is mainly concerned with showing that the expense is a deadweight cost (e.g., Ferris and Chance (1987), (1991), Freeman and Brown (2001), and Dukes, English, and Davis (2006)). In the work reviewed at the beginning of this paper (Bergstresser et al. (2009), Christoffersen et al. (2013), and Del Guercio and Reuters (2014)), attempts are being made to understand apparent misselling in mutual funds as a consequence of skewed broker incentives. Our contribution to this literature lies in our focus on the effects of regulated caps on mutual fund brokers' compensation, which theory suggests are detrimental. We trace the trends of mutual fund marketing and distribution fees and identify the point at which a structural shift occurs among funds toward charging the maximum permissible levels of such fees. We then motivate our hypotheses around this structural break point.

Our first hypothesis is that the cap on 12b-1 fees explains the association of fund underperformance associated with skewed broker incentives and is formally stated as follows:

Hypothesis 1 . The negative relation between indirect brokerage fees and fund performance prevails after the mutual fund industry shifts toward charging the maximum level of $12 b-1$ fees. 
The idea that indirect brokerage commissions incentivize learning about financial products prior to the sale decision is consistent with the role of search costs in the flow-performance relationship shown by Sirri and Tufano (1998) and many others since then. In a rational model in which investors learn about the ability of fund managers at least partly based on past performance, Huang et al. (2007) show that the well-known asymmetric flow-performance relationship can be explained by investors' search costs. Such search costs create a hurdle that investors (advisors) use as a focal point to determine which funds to follow and eventually invest in (recommend) based on the funds' past performance. Whether search costs are incurred by investors out of pocket or indirectly through mutual funds' marketing and distribution expenses, the two are complementary in reducing investors' participation costs. For funds with lower participation costs, the effect of this hurdle is to shift higher flow sensitivity to medium performance and lower flow sensitivity to high performance. Investors choose high-visibility funds and those that spend more on advertising, distribution, and marketing, because these incur less direct participation costs and vice versa.

This key insight by Huang et al. (2007) helps us motivate our second hypothesis. We hypothesize that regulated caps on $12 \mathrm{~b}-1$ fees limit the ability of fund managers to adequately compensate brokers to reduce investors' search costs by learning about suitable products on their behalf. As a result, the flow-performance relationship changes once funds start charging marketing and distribution fees at the regulated cap, leading to our second hypothesis:

Hypothesis 2. Caps on mutual fund brokerage fees move the sensitivity of flows to higher fund performance levels after the mutual fund industry shifts to charging maximum levels of $12 \mathrm{~b}-1$ fees.

\section{Data Sources and Sample Construction}

\section{A. Data}

Our main data source for fund characteristics, including fund size, age, turnover, investment objective, fund returns, and fund fees (e.g., expense ratios, management, and 12b-1 fees and front- and rear-end loads), is the Center for Research in Security Prices (CRSP) Mutual Fund Database. While the CRSP database includes 12b-1 fees from 1992, our sample period covers only the period 1993-2012 to match the introduction of a cap on 12b-1 fees on July 7, 1993, for both load (capped at $1 \%$ ) and no-load (capped at $0.25 \%$ ) funds. ${ }^{12}$ To eliminate outliers, all of our variables are winsorized at the top and bottom percentiles. Such a process results in all data below the first percentile being set to the first percentile and the data above the 99th percentile set to the 99th percentile.

To facilitate comparison with the prior literature on performance persistence and flow-performance sensitivity, in particular, the work of Huang et al. (2007),

\footnotetext{
${ }^{12}$ We eliminate the year before 1993 , because, then, funds were allowed to charge $12 \mathrm{~b}-1$ fees above the cap. While it would be interesting to examine fund fee-setting behavior before and after the imposition of a cap on $12 \mathrm{~b}-1$ fees, we are unable to find a longer history of $12 \mathrm{~b}-1$ fees data prior to 1992 in other standard mutual fund databases, such as Morningstar Direct.
} 
this study focuses on actively managed U.S. domestic equity mutual funds. ${ }^{13}$ Following Chen, Hong, Huang, and Kubik (2004), we exclude index, international, and specialized sector funds from our sample. The unit of observation for our study is at the fund share class level to account for differences in marketing and distribution fee structure. We use one return series per fund, which is consistent with our objective of capturing differences in fee structure information at the share class level. This information would be lost if we were to retain the return history for the longest existing share class or to perform asset weighting at the portfolio level.

Next, we apply two criteria to eliminate two known potential biases associated with the CRSP database. First, to address incubation bias, we exclude funds that existed prior to the reported fund starting date (Evans (2010)) and exclude observations whose fund names are missing from the CRSP database. Second, we exclude funds with AUM of less than \$15 million, since only successful funds enter the database (Elton, Gruber, and Blake (2001)). We also separate our analyses between load and no-load funds, because the regulations impose different 12b-1 fee caps for these 2 fund types. Load funds charge either front- or rear-end loads, while no-load funds charge neither. ${ }^{14}$

This study examines fee-setting behavior. Brokers receive compensation through shared sales loads, 12b-1 fees, and marketing and sales support through arrangements with fund families (Stoughton et al. (2011)). Accordingly, we should ideally conduct our analyses at the fund family level. Fund families charge different $12 \mathrm{~b}-1$ fees for each share class, however; thus, it is impossible to aggregate $12 \mathrm{~b}-1$ fees at the family level. Therefore, we perform our analyses at the fund share class level, following Bergstresser et al. (2009). Our final sample of U.S. domestic equity funds in terms of share-class-month observations ranges from 959 in 1993 to 6,089 in 2012. In our multivariate tests, we account for unobserved fund family characteristics by controlling for family size and family revenue. We also cluster the standard errors by fund family.

Our key brokerage fee variables are as follows: 12B-1_FEE is the charge to investors for fund marketing and distribution expenses. CAP is a binary variable that equals 1 if the fund charged $12 \mathrm{~b}-1$ fees at the regulatory ceiling (1\% for load funds and $0.25 \%$ for no-load funds), and 0 otherwise. 12B-1_GAP is the percentage difference between the 12b-1 fee cap and the actual 12b-1 fees charged by funds. Other fund level variables are listed and defined in the Appendix.

\footnotetext{
${ }^{13}$ We use the crsp_obj_cd variable in the CRSP database to classify equity funds. Our data are not subject to survivorship bias, because we include both surviving and dead funds.

${ }^{14}$ To classify funds into load and no-load funds at the fund share class level, we implement the following process. First, funds that are observed to charge any form of load fees are categorized as load funds. Second, for funds that do not report any load fees, we then look at their $12 \mathrm{~b}-1$ fees to determine whether these exceed $0.25 \%$. If so, we reclassify them as load funds. Missing data on both loads and 12b-1 fees are treated as missing values. As for the rest of the funds, we treat them as no-load funds and make sure that they do not charge any form of load fees or $12 \mathrm{~b}-1$ fees exceeding $0.25 \%$, in line with the prohibition under the 1993 NASD rules, of calling funds no-load funds if they charge front-end, rear-end, or $12 \mathrm{~b}-1$ fees in excess of $0.25 \%$.
} 


\section{B. Descriptive Statistics}

We start by reporting the trend of 12B-1_FEE and 12B-1_GAP for equity funds and the tendency of managers to charge 12b-1 fees at the cap in Panel A of Table $1 .{ }^{15}$ We present the results for the full sample and load and no-load fund subsamples to show that the $12 \mathrm{~b}-1$ fee increases regardless of load status. The average 12B-1_FEE (12B-1_GAP) increases (decreases) for the full sample from $0.207 \%(0.484 \%)$ in 1993 to a peak (trough) of $0.620 \%(0.295 \%)$ in 2001 . This jump is also reflected in the proportion of funds that charge the fee exactly at the regulated cap, $41.18 \%$ in 2001 compared to $10.29 \%$ in 1993 . Over the full sample period, the number of load (no-load) funds charging 12b-1 fees at the cap increases from $15.30 \%$ (4.47\%) in 1993 to $25.74 \%$ (66.86\%) in 2012.

In the second half of our sample period, we observe a relatively stable trend. These results confirm the trends illustrated in Figure 1. In Panel B of Table 1, to determine the structural break in the time series of 12b-1 Gap and funds' tendency to charge 12b-1 fees at the cap, we perform 2 forms of structural break tests. First, using the Quandt (1960) likelihood ratio (QLR) test to examine our series for unknown breaks, we find the maximum QLR statistics for the variable 12B-1_GAP (632.96) and CAP $(19,311.50)$ to occur in year 2000. Second, we calculate the Chow (1960) $F$-statistic and $p$-value from this statistic in year 2000 and find that there is a structural break in the time series of 12B-1_GAP ( $F$-value $=364.37$, $p$-value $<0.0001)$ and CAP $(F$-value $=170.19, p$-value $<0.0001)$ variables in 2000. As such, we conduct our analysis on the pre- and post-2000 subperiods, as well as the entire sample. In Panel $\mathrm{C}$ of Table 1, we report the other distribution moments (e.g., standard deviation, skewness, and kurtosis) for the 12B-1_FEE, 12B-1_GAP, and CAP variables. While the standard deviation of all variables remained largely unchanged, we find the skewness of 12B-1_FEE and CAP decreases from pre-2000 to post-2000 periods. This is unsurprising, given that more funds charge 12b-1 fees toward the cap, as documented in Figure 1. Also, the higher kurtosis level for no-load funds during the pre-2000 period is due to the presence of heavier tails in the 12B-1_FEE and CAP distributions.

Our discussion of descriptive statistics presented in Table 2 is in terms of the full sample, as well as the periods before and after 2000, given the structural break in our key variables of interest (i.e., 12B-1_GAP and CAP). ${ }^{16}$ The average 12b-1 fee almost doubles from $0.29 \%$ in the pre-2000 period to $0.56 \%$ after 2000 . All other fees remain stable across the 2 subperiods. ${ }^{17}$

Fund characteristics are consistent with a rapidly expanding mutual fund industry, most saliently in terms of family size. While the average fund family almost triples in size from $\$ 32.356$ billion before 2000 to $\$ 90.769$ billion after 2000 , individual fund size actually shrinks by $13 \%$, from $\$ 530$ million to $\$ 461$ million.

\footnotetext{
${ }^{15}$ The variable CAP is a binary indicator equal to 1 if funds charge $12 \mathrm{~b}-1$ fees at the cap (1\% for load funds and $0.25 \%$ for no-load funds), and 0 otherwise.

${ }^{16}$ We also construct a correlation matrix (unreported) on our key control variables (i.e., $\ln (\mathrm{SIZE})$, $\ln ($ AGE), $\ln$ (FAMILY_SIZE), TURNOVER, FUND_REVENUE, FAMILY_REVENUE, HERFINDAHL, VOLATILITY, FUND_FLOW, and FUND_ALPHA) based on the full sample. Our calculation yields a low condition index of 2.361 for the matrix, showing there is no multicollinearity.

${ }^{17}$ Following Barber, Odean, and Zheng (2005), we compute the NON_12B-1_FEE component by subtracting $12 \mathrm{~b}-1$ fees from the expense ratio.
} 
TABLE 1

\section{Statistics on Funds Charging 12b-1 Fee at and below the Cap}

Panel A of Table 1 reports the average 12B-1_FEE, 12B-1_GAP, and proportions of the U.S. equity mutual fund market charging 12b-1 fees at the cap, as indicated by CAP = 1, from 1993 to 2012. Load funds are funds that levy investors' entry (front-end) or exit (back-end) fees or $12 \mathrm{~b}-1$ fees greater than $0.25 \%$, while no-load funds are funds that do not charge any loads or a $12 \mathrm{~b}-1$ fee exceeding $0.25 \%$. Pane B reports the results of 2 structural break tests (i.e., the Quandt likelihood ratio and the Chow tests) based on the 12B-1_GAP and CAP variables. Panel C reports other distribution moments (i.e., standard deviation, skewness, and kurtosis) of the 12B-1 FEE, 12B-1 GAP, and CAP variables for the full sample, as well as the pre-2000 and post-2000 periods.

Panel A. Average 12b-1 Fee, 12b-1 Gap, and Cap

\begin{tabular}{|c|c|c|c|}
\hline \multirow[b]{2}{*}{ Year } & \multicolumn{3}{|c|}{ All Funds } \\
\hline & 12B-1_FEE (\%) & 12B-1_GAP (\%) & $\mathrm{CAP}=1$ \\
\hline 1993 & 0.207 & 0.484 & $10.29 \%$ \\
\hline 1994 & 0.219 & 0.455 & $11.49 \%$ \\
\hline 1995 & 0.235 & 0.429 & $15.15 \%$ \\
\hline 1996 & 0.252 & 0.405 & $17.74 \%$ \\
\hline 1997 & 0.273 & 0.388 & $19.57 \%$ \\
\hline 1998 & 0.303 & 0.360 & $22.14 \%$ \\
\hline 1999 & 0.391 & 0.339 & $24.80 \%$ \\
\hline 2000 & 0.608 & 0.304 & $38.17 \%$ \\
\hline 2001 & 0.620 & 0.295 & $41.18 \%$ \\
\hline 2002 & 0.616 & 0.304 & $41.72 \%$ \\
\hline 2003 & 0.608 & 0.308 & $41.52 \%$ \\
\hline 2004 & 0.606 & 0.316 & $39.18 \%$ \\
\hline 2005 & 0.598 & 0.330 & $35.61 \%$ \\
\hline 2006 & 0.584 & 0.335 & $34.10 \%$ \\
\hline 2007 & 0.564 & 0.347 & $33.19 \%$ \\
\hline 2008 & 0.537 & 0.352 & $32.59 \%$ \\
\hline 2009 & 0.515 & 0.346 & $33.98 \%$ \\
\hline 2010 & 0.507 & 0.346 & $33.60 \%$ \\
\hline 2011 & 0.501 & 0.348 & $33.36 \%$ \\
\hline 2012 & 0.487 & 0.353 & $33.05 \%$ \\
\hline
\end{tabular}

Load Funds

\begin{tabular}{|c|c|c|}
\hline \multicolumn{3}{|c|}{ Load Funds } \\
\hline 12B-1_FEE (\%) & 12B-1_GAP (\%) & $\mathrm{CAP}=1$ \\
\hline 0.362 & 0.668 & $15.30 \%$ \\
\hline 0.387 & 0.632 & $19.80 \%$ \\
\hline 0.414 & 0.596 & $22.19 \%$ \\
\hline 0.464 & 0.559 & $27.41 \%$ \\
\hline 0.506 & 0.523 & $30.98 \%$ \\
\hline 0.547 & 0.475 & $29.22 \%$ \\
\hline 0.652 & 0.410 & $34.69 \%$ \\
\hline 0.669 & 0.337 & $37.99 \%$ \\
\hline 0.672 & 0.326 & $40.14 \%$ \\
\hline 0.657 & 0.333 & $39.18 \%$ \\
\hline 0.664 & 0.339 & $39.54 \%$ \\
\hline 0.648 & 0.345 & $35.70 \%$ \\
\hline 0.637 & 0.358 & $31.52 \%$ \\
\hline 0.626 & 0.367 & $32.34 \%$ \\
\hline 0.612 & 0.383 & $30.51 \%$ \\
\hline 0.586 & 0.401 & $28.42 \%$ \\
\hline 0.589 & 0.411 & $28.57 \%$ \\
\hline 0.582 & 0.416 & $27.81 \%$ \\
\hline 0.570 & 0.422 & $26.23 \%$ \\
\hline 0.562 & 0.434 & $25.74 \%$ \\
\hline
\end{tabular}

No-Load Funds

\begin{tabular}{|c|c|c|}
\hline 12B-1_FEE (\%) & 12B-1_GAP (\%) & $\mathrm{CAP}=1$ \\
\hline 0.025 & 0.222 & $4.47 \%$ \\
\hline 0.026 & 0.225 & $7.74 \%$ \\
\hline 0.027 & 0.224 & $8.47 \%$ \\
\hline 0.028 & 0.222 & $9.70 \%$ \\
\hline 0.027 & 0.224 & $9.18 \%$ \\
\hline 0.029 & 0.219 & $8.89 \%$ \\
\hline 0.170 & 0.212 & $49.22 \%$ \\
\hline 0.194 & 0.061 & $62.87 \%$ \\
\hline 0.193 & 0.056 & $59.62 \%$ \\
\hline 0.188 & 0.059 & $59.46 \%$ \\
\hline 0.193 & 0.059 & $64.44 \%$ \\
\hline 0.187 & 0.061 & $62.77 \%$ \\
\hline 0.180 & 0.066 & $58.96 \%$ \\
\hline 0.177 & 0.073 & $57.88 \%$ \\
\hline 0.173 & 0.077 & $54.75 \%$ \\
\hline 0.184 & 0.072 & $58.31 \%$ \\
\hline 0.188 & 0.059 & $59.73 \%$ \\
\hline 0.194 & 0.058 & $62.26 \%$ \\
\hline 0.195 & 0.054 & $63.71 \%$ \\
\hline 0.194 & 0.055 & $66.86 \%$ \\
\hline
\end{tabular}


TABLE 1 (continued)

Statistics on Funds Charging 12b-1 Fee at and below the Cap

\begin{tabular}{|c|c|c|c|c|c|c|c|c|c|}
\hline \multicolumn{10}{|c|}{ Panel B. Structural Break Test } \\
\hline \multirow[b]{2}{*}{ Statistics } & & \multicolumn{3}{|c|}{$\begin{array}{l}\text { Quandt Likelihood Ratio (QLR) } \\
\text { Test (Unknown Breaks) }\end{array}$} & & & \multicolumn{3}{|c|}{$\begin{array}{c}\text { Chow Test } \\
\text { (Known Breaks = Year 2000) }\end{array}$} \\
\hline & \multicolumn{2}{|r|}{ 12B-1_GAP } & \multicolumn{2}{|c|}{ CAP } & \multicolumn{2}{|c|}{ Statistics } & 12B-1_GAP & & CAP \\
\hline $\begin{array}{l}\text { Max QLR statistic } \\
\text { Year of maximum }\end{array}$ & \multicolumn{2}{|r|}{$\begin{array}{l}632.96 \\
2000\end{array}$} & \multicolumn{2}{|c|}{$\begin{array}{l}19,311.50 \\
2000\end{array}$} & \multicolumn{2}{|c|}{$\begin{array}{l}\text { Chow } F \text {-value } \\
\text { Chow } p \text {-value }\end{array}$} & $\begin{array}{l}364.37 \\
<0.0001\end{array}$ & & $\begin{array}{l}170.19 \\
<0.0001\end{array}$ \\
\hline \multicolumn{10}{|c|}{ Panel C. Other Distribution Moments for $12 \mathrm{~b}-1$ Fee, $12 b-1$ Gap, and Cap } \\
\hline & \multicolumn{3}{|c|}{ All Funds } & \multicolumn{3}{|c|}{ Load Funds } & \multicolumn{3}{|c|}{ No-Load Funds } \\
\hline & 12B-1_FEE (\%) & 12B-1_GAP (\%) & $\underline{\mathrm{CAP}=1}$ & 12B-1_FEE (\%) & 12B-1_GAP (\%) & $\mathrm{CAP}=1$ & 12B-1_FEE (\%) & 12B-1_GAP (\%) & $\underline{\mathrm{CAP}}=1$ \\
\hline $\begin{array}{l}\text { Standard Deviation } \\
\text { Full sample } \\
\text { Pre-2000 } \\
\text { Post-2000 }\end{array}$ & $\begin{array}{l}0.383 \\
0.389 \\
0.351\end{array}$ & $\begin{array}{l}0.343 \\
0.389 \\
0.351\end{array}$ & $\begin{array}{l}0.466 \\
0.431 \\
0.468\end{array}$ & $\begin{array}{l}0.363 \\
0.389 \\
0.351\end{array}$ & $\begin{array}{l}0.363 \\
0.389 \\
0.351\end{array}$ & $\begin{array}{l}0.464 \\
0.431 \\
0.468\end{array}$ & $\begin{array}{l}0.117 \\
0.077 \\
0.094\end{array}$ & $\begin{array}{l}0.117 \\
0.077 \\
0.094\end{array}$ & $\begin{array}{l}0.474 \\
0.286 \\
0.489\end{array}$ \\
\hline $\begin{array}{l}\text { Skewness } \\
\text { Full sample } \\
\text { Pre-2000 } \\
\text { Post-2000 }\end{array}$ & $\begin{array}{r}0.326 \\
0.299 \\
-0.010\end{array}$ & $\begin{array}{r}0.337 \\
-0.299 \\
0.010\end{array}$ & $\begin{array}{l}0.783 \\
1.172 \\
0.752\end{array}$ & $\begin{array}{r}0.005 \\
0.299 \\
-0.010\end{array}$ & $\begin{array}{r}-0.005 \\
-0.299 \\
0.010\end{array}$ & $\begin{array}{l}0.809 \\
1.172 \\
0.752\end{array}$ & $\begin{array}{r}0.317 \\
2.377 \\
-1.055\end{array}$ & $\begin{array}{r}-0.317 \\
-2.377 \\
1.055\end{array}$ & $\begin{array}{r}0.674 \\
2.862 \\
-0.434\end{array}$ \\
\hline $\begin{array}{l}\text { Kurtosis } \\
\text { Full sample } \\
\text { Pre-2000 } \\
\text { Post-2000 }\end{array}$ & $\begin{array}{l}1.470 \\
1.470 \\
1.187\end{array}$ & $\begin{array}{l}1.486 \\
1.470 \\
1.187\end{array}$ & $\begin{array}{l}1.613 \\
2.373 \\
1.566\end{array}$ & $\begin{array}{l}1.281 \\
1.470 \\
1.187\end{array}$ & $\begin{array}{l}1.281 \\
1.470 \\
1.187\end{array}$ & $\begin{array}{l}1.654 \\
2.373 \\
1.566\end{array}$ & $\begin{array}{l}1.190 \\
6.849 \\
2.338\end{array}$ & $\begin{array}{l}1.190 \\
6.849 \\
2.338\end{array}$ & $\begin{array}{l}1.454 \\
9.191 \\
1.188\end{array}$ \\
\hline
\end{tabular}


TABLE 2

Descriptive Statistics of Equity Funds

Table 2 provides descriptive statistics for U.S. equity funds before and after 2000. The variable FUND_SIZE is the fund's total net assets (in \$millions); In(SIZE) is the natural logarithm of fund size; FUND_AGE is the number of years since the fund's inception; In(AGE) is the natural logarithm of fund age; FAMILY_SIZE is total net assets at the fund management company level (in \$millions); In(FAMILY SIZE) is the natural logarithm of family size; TURNOVER is the portfolio turnover of the fund, calculated by dividing average assets during the period by the lesser of the value of purchases and the value of sales during the same period; HERFINDAHL is a measure of mutual fund industry concentration; VOLATILITY is the standard deviation of a fund's net returns over the past 12 months; FUND_FLOW measures the percentage growth of a fund that is due to new investments, following Sirri and Tufano (1998); FUND_REVENUE is the expense ratio times the fund's AUM; FAMILY_REVENUE is the aggregate of fund revenues at the fund family level; 12B-1_FEE is the fee paid for the marketing and distribution of funds; NON_12B-1_FEE is calculated by subtracting the $12 \mathrm{~b}-1$ fee from the expense ratio; MANAGEMENT_FEE is the fee paid out of fund assets to the funds' investment adviser; EXPENSE_RATIO is the ratio of the fund's operating expense over total net assets; TOTAL_FEE is the expense ratio plus one-seventh of front-end loads; GROSS_RETURN is the monthly net return plus one-12th of the reported expense ratio; NET_RETURN is the monthly net of expense returns; and FUND_GROSS(NET)_ALPHA is the monthly fund's gross (net) returns adjusted using Carhart's (1997) 4-factor model and the APB following Hunter et al. (2014).

\begin{tabular}{|c|c|c|c|}
\hline Variables & All & Pre-2000 & Post-2000 \\
\hline \multicolumn{4}{|l|}{ Panel A. Fund Characteristics } \\
\hline $\begin{array}{l}\text { FUND_SIZE (\$millions) } \\
\text { In(SIZE) } \\
\text { FUND_AGE (years) } \\
\text { In(AGE) } \\
\text { FAMILY_SIZE (\$millions) } \\
\text { In(FAMILY_SIZE) } \\
\text { TURNOVER (\%) } \\
\text { HERFINDAHL } \\
\text { VOLATILITY } \\
\text { FUND_FLOW (\%) } \\
\text { FUND_REVENUE (\$millions) } \\
\text { FAMILY_REVENUE (\$millions) }\end{array}$ & $\begin{array}{r}476.688 \\
4.923 \\
9.668 \\
1.862 \\
78,794.23 \\
9.819 \\
86.372 \\
2.993 \\
4.940 \\
1.374 \\
6.018 \\
758.520\end{array}$ & $\begin{array}{r}530.219 \\
5.038 \\
9.951 \\
1.686 \\
32,356.35 \\
8.876 \\
83.119 \\
2.881 \\
4.434 \\
2.165 \\
6.803 \\
353.005\end{array}$ & $\begin{array}{r}460.638 \\
4.894 \\
9.720 \\
1.918 \\
90,768.52 \\
10.049 \\
86.359 \\
3.057 \\
4.945 \\
1.137 \\
5.691 \\
857.595\end{array}$ \\
\hline \multicolumn{4}{|l|}{ Panel B. Fund Fees } \\
\hline $\begin{array}{l}\text { 12B-1_FEE (\%) } \\
\text { NON_12B-1_FEE (\%) } \\
\text { MANAGEMENT_FEE (\%) } \\
\text { EXPENSE_RATIO (\%) } \\
\text { TOTAL_FEE (\%) }\end{array}$ & $\begin{array}{l}0.491 \\
1.012 \\
0.670 \\
1.299 \\
1.456\end{array}$ & $\begin{array}{l}0.285 \\
1.041 \\
0.682 \\
1.276 \\
1.468\end{array}$ & $\begin{array}{l}0.560 \\
0.999 \\
0.669 \\
1.300 \\
1.448\end{array}$ \\
\hline \multicolumn{4}{|l|}{ Panel C. Fund Returns } \\
\hline $\begin{array}{l}\text { GROSS_RETURN (\%) } \\
\text { NET_RETURN (\%) } \\
\text { FUND_GROSS_ALPHA (\%) } \\
\text { FUND_NET_ALPHA (\%) }\end{array}$ & $\begin{array}{r}0.700 \\
0.595 \\
0.017 \\
-0.091\end{array}$ & $\begin{array}{r}1.648 \\
1.563 \\
-0.074 \\
-0.176\end{array}$ & $\begin{array}{r}0.513 \\
0.425 \\
0.025 \\
-0.084\end{array}$ \\
\hline
\end{tabular}

This fragmentation of the industry at the fund level is consistent with the structural change in competition in the late 1990s, as reported by Wahal and Wang (2011).

\section{Methods and Empirical Results}

\section{A. Performance Measures (Time-Varying Alpha)}

Previous studies, such as those of Kosowski, Timmermann, Wermers, and White (2006) and Fama and French (2010), document the importance of addressing the non-normalities in the cross-sectional distribution of alphas and the non-normalities of individual fund alpha distributions. Moreover, biases inherent in using constant alphas are now well known, and authors, such as Ferson and Schadt (1996), Berzins, Liu, and Trzcinka (2013), and Hunter, Kandel, Kandel, and Wermers (2014), now model alphas with methods that allow for the alphas to change over the time series. ${ }^{18}$

\footnotetext{
${ }^{18}$ We thank Charles Trzcinka (the referee) for raising this point.
} 
Accordingly, we follow the approach of Hunter et al. (2014), who account for commonalities in mutual fund strategies and the time-series correlation of residuals between individual funds. We use the Carhart (1997) 4-factor model augmented with an additional factor, called an active peer benchmark (APB), that represents an equal investment in all same-category funds. Similar to Hunter et al. (2014), we use the "best-fit" primary benchmark, as assigned by Cremers and Petajisto (2009), to minimize the agency issue surrounding self-designated benchmarks, as documented by Sensoy (2009). To qualify as a group, we require at least 5 funds following the same best-fit benchmark at time $t$ and that each fund have at least 30 nonmissing returns during the 3-year estimation period.

The APB return $\left(r_{\mathrm{APB}_{i, t}}\right)$ is defined as the average gross excess return of the active peer group to which fund $i$ belongs, as follows:

$$
r_{\mathrm{APB}_{i, t}}=\frac{1}{N_{\mathrm{APB}_{i}}} \sum_{i=1}^{N_{\mathrm{APB}_{i}}} r_{i, t},
$$

where $N_{\mathrm{APB}_{i}}$ equals the number of funds in the APB to which fund $i$ belongs and $r_{i, t}$ equals the fund's monthly net return plus one-12th of expense ratios minus the return on T-bills.

The augmented model involves 2-stage regressions. In the first stage, using the return of the equal-weighted active peer group $\left(r_{\mathrm{APB}_{i, t}}\right)$ that fund $i$ belongs to at the end of the given 3-year period, we run the following model and retain the residual estimates $\epsilon_{\mathrm{APB}_{i, t}}$ :

$$
r_{\mathrm{APB}_{i, t}}=\alpha_{i}+\beta_{1}\left(R_{m}-R_{f}\right)_{t}+\beta_{2} \mathrm{SMB}_{t}+\beta_{3} \mathrm{HML}_{t}+\beta_{4} \mathrm{UMD}_{t}+e_{i, t},
$$

where $R_{m}$ is the monthly return on the CRSP value-weighted portfolio (New York Stock Exchange/American Stock Exchange/NASDAQ); $R_{f}$ is the risk-free rate (T-bills); SMB is small minus big, which accounts for the spread in returns between small and large funds based on total net AUM; HML is high minus low, which accounts for the spread in returns between value and growth funds, and UMD represents the momentum factor loadings (available via Kenneth French's Web site (http://mba.tuck.dartmouth.edu/pages/faculty/ken.french/data_library .html)).

In the second stage, we add the first-stage 4-factor regression residuals for the APB, $\epsilon_{\mathrm{APB}_{i, t}}$, and run the following model for each individual mutual fund $i$ :

$$
\begin{aligned}
r_{i, t}= & \alpha_{i}+\beta_{1}\left(R_{m}-R_{f}\right)_{t}+\beta_{2} \mathrm{SMB}_{t} \\
& +\beta_{3} \mathrm{HML}_{t}+\beta_{4} \mathrm{UMD}_{t}+\lambda_{i} \epsilon_{\mathrm{APB}_{i, t}}+e_{i, t} .
\end{aligned}
$$

As argued by Hunter et al. (2014), the above regression helps to control for commonalities in idiosyncratic risk taking by funds within the same APB group. ${ }^{19}$

\section{B. Empirical Tests}

The questions targeted by our tests are i) whether the structural break we formally show in Table 1 is in the direction of charging $12 \mathrm{~b}-1$ fees at the regulated

\footnotetext{
${ }^{19}$ See Hunter et al. (2014) for a more detailed description of the augmented model.
} 
cap in the cross section of equity mutual funds, ii) whether the regulated caps on indirect brokerage fees are associated with negative fund performance once there is a shift toward charging the maximum level of $12 \mathrm{~b}-1$ fees, and iii) whether there is evidence that the movement toward charging maximum fund brokerage fees affects the intermediaries' learning.

\section{Analysis of Funds' Marketing and Distribution Efforts}

We have shown in Table 1 that 12b-1 fees rise rapidly and then stabilize in 2000, suggesting a larger proportion of equity mutual funds are now charging the maximum allowed. One may argue that the trend of $12 b-1$ fees is due to unobserved heterogeneity among different equity funds. To confirm whether fund management companies persistently charge $12 \mathrm{~b}-1$ fees closer to the cap, we implement a regression analysis of the fees after controlling for various factors that influence funds' fee-setting behavior. Our dependent variable, 12B-1_GAP, is the percentage difference between the 12b-1 fee cap and the actual 12b-1 fees charged by funds. The regression specification is as follows:

$$
\begin{aligned}
& \text { 12B-1_GAP }{ }_{i, t}=\beta_{0}+\beta_{1} \ln (\mathrm{SIZE})_{i, t}+\beta_{2} \ln (\mathrm{AGE})_{i, t} \\
& +\beta_{3} \ln (\text { FAMILY_SIZE })_{i, t}+\beta_{4} \text { TURNOVER }_{i, t} \\
& +\beta_{5} \text { FUND_REVENUE }_{i, t}+\beta_{6} \text { FAMILY_REVENUE }_{i, t} \\
& +\beta_{7} \text { HERFINDAHL }_{i, t}+\beta_{8} \text { VOLATILITY }_{i, t} \\
& +\beta_{9} \text { FUND_FLOW }_{i, t-1}+\beta_{10} \text { FUND_ALPHA }_{i, t-1} \\
& +\beta_{11} \text { YEAR_DUMMIES }{ }_{i, t}+\varepsilon_{i, t} \text {. }
\end{aligned}
$$

The regressors used in equation (4) are described in the Appendix and are hypothesized to be related to fee setting in line with the literature (e.g., Malhotra and McLeod (1997), Tufano and Sevick (1997), LaPlante (2001), Geranio and Zanotti (2005), and Dukes et al. (2006)). ${ }^{20}$ We focus specifically on the yearly time dummy variables to track $12 \mathrm{~b}-1$ fee-setting tendencies over the sample period. If funds set $12 \mathrm{~b}-1$ fees toward the cap over time, we should observe a decline in the regression coefficients of the year dummies.

Table 3 shows statistically significant support for our conjecture for both load and no-load funds; the magnitude of 12B-1_GAP decreases, as reflected in the coefficients of the yearly dummies from 1993 to 2001 . Thereafter, the phenomenon dissipates. The difference in magnitude between the 1993 and 2001 coefficients in model 1 indicates that load funds shift 12b-1 fees toward the regulated cap by a considerable $71 \% .{ }^{21}$ No-load funds shift $12 \mathrm{~b}-1$ fees toward the regulated cap by approximately the same magnitude. ${ }^{22}$ This evidence marks the point at which a greater proportion of the mutual fund industry starts to routinely charge $12 \mathrm{~b}-1$

\footnotetext{
${ }^{20}$ The previous literature suggests that fund size and age could be nonlinearly related to the total expense ratio; accounting for this nonlinear relationship requires the natural log transformations for both variables.

${ }^{21} 12 \mathrm{~B}-1$ _GAP decreases by $71 \%$ [(0.037 - 0.128)/(0.128)] from 1993 to 2001.

${ }^{22}$ For no-load funds, 12B-1_GAP decreases by 76\% [(0.043 - 0.182)/(0.182)] from 1993 to 2001; 12B-1_GAP decreases further from 2002 through 2010, consistent with the graphical evidence in Figure 1.
} 


\section{TABLE 3}

\section{Analysis of Funds' Proximity to the 12b-1 Fee Cap}

Table 3 provides the results of regressions relating the level of $12 \mathrm{~b}-1$ Gap to the characteristics of equity funds. The dependent variable, 12B-1_GAP, is the difference (percentage) between the $12 \mathrm{~b}-1$ fee cap and the actual $12 \mathrm{~b}-1 \mathrm{charged}$ by funds. All independent variables are measured at time $t$ unless specified otherwise. The independent variables are as follows: In(SIZE) is the natural logarithm of fund size; In(AGE) is the natural logarithm of fund age; In(FAMILY SIZE) is the natural logarithm of family size; TURNOVER is the portfolio turnover of the fund, calculated by dividing average assets during the period by the lesser of the value of purchases and the value of sales during the same period; FUND_REVENUE is the expense ratio times the fund's AUM; FAMILY REVENUE is the aggregate of fund revenues at the fund family level; HERFINDAHL is a measure of mutual fund industry concentration; VOLATILITY is the standard deviation of a fund's net returns over the past 12 months; FUND_FLOW measures the percentage growth of a fund that is due to new investments, following Sirri and Tufano (1998); and FUND ALPHA is monthly fund net returns adjusted using Carhart's (1997) 4-factor model and the APB, as proposed by Hunter et al. (2014). Style fixed effects are incorporated to control for unobserved heterogeneity of investment styles over the sample period. Standard errors are clustered at the fund family level and reported in parentheses. ${ }^{* \star}$ and ${ }^{* \star *}$ indicate significance at the $5 \%$ and $1 \%$ levels, respectively.

\begin{tabular}{|c|c|c|}
\hline & Load Fund & No-Load Fund \\
\hline Variables & 1 & 2 \\
\hline Intercept & $\begin{array}{l}0.553^{* * *} \\
(0.155)\end{array}$ & $\begin{array}{c}-0.046 \\
(0.084)\end{array}$ \\
\hline $\ln (S I Z E)$ & $\begin{array}{l}0.068^{* \star \star} \\
(0.009)\end{array}$ & $\begin{array}{c}0.007 \\
(0.005)\end{array}$ \\
\hline $\ln (A G E)$ & $\begin{array}{l}0.069^{\star \star *} \\
(0.011)\end{array}$ & $\begin{array}{c}-0.002 \\
(0.004)\end{array}$ \\
\hline In(FAMILY_SIZE) & $\begin{array}{c}-0.048^{* \star *} \\
(0.007)\end{array}$ & $\begin{array}{c}0.006^{\star *} \\
(0.003)\end{array}$ \\
\hline TURNOVER & $\begin{array}{c}0.014 \\
(0.007)\end{array}$ & $\begin{array}{c}-0.005^{\star \star} \\
(0.003)\end{array}$ \\
\hline FUND_REVENUE & $\begin{array}{c}-0.105 \\
(0.076)\end{array}$ & $\begin{array}{c}-0.024 \\
(0.018)\end{array}$ \\
\hline FAMILY_REVENUE & $\begin{array}{c}0.001 \\
(0.001)\end{array}$ & $\begin{array}{c}-0.000 \\
(0.001)\end{array}$ \\
\hline HERFINDAHL & $\begin{array}{l}0.118^{\star * \star} \\
(0.013)\end{array}$ & $\begin{array}{c}0.016 \\
(0.009)\end{array}$ \\
\hline VOLATILITY & $\begin{array}{c}-0.004^{\star *} \\
(0.002)\end{array}$ & $\begin{array}{c}-0.001 \\
(0.001)\end{array}$ \\
\hline FUND_FLOW ${ }_{t-1}$ & $\begin{array}{l}0.041^{* \star *} \\
(0.006)\end{array}$ & $\begin{array}{c}-0.007^{* *} \\
(0.003)\end{array}$ \\
\hline FUND_ALPHA $A_{t-1}$ & $\begin{array}{c}-0.001 \\
(0.009)\end{array}$ & $\begin{array}{c}0.002 \\
(0.006)\end{array}$ \\
\hline Y1993 & $\begin{array}{l}0.128^{\star \star \star} \\
(0.029)\end{array}$ & $\begin{array}{l}0.182^{\star \star *} \\
(0.014)\end{array}$ \\
\hline Y1994 & $\begin{array}{l}0.119^{\star * *} \\
(0.029)\end{array}$ & $\begin{array}{l}0.185^{\star \star \star} \\
(0.012)\end{array}$ \\
\hline Y1995 & $\begin{array}{l}0.103^{\star \star \star} \\
(0.032)\end{array}$ & $\begin{array}{l}0.190^{\star \star \star} \\
(0.012)\end{array}$ \\
\hline Y1996 & $\begin{array}{l}0.100^{* * *} \\
(0.031)\end{array}$ & $\begin{array}{l}0.189^{\star \star \star} \\
(0.011)\end{array}$ \\
\hline Y1997 & $\begin{array}{l}0.110^{* * *} \\
(0.030)\end{array}$ & $\begin{array}{l}0.195^{\star \star \star} \\
(0.010)\end{array}$ \\
\hline Y1998 & $\begin{array}{l}0.118^{\star \star \star} \\
(0.028)\end{array}$ & $\begin{array}{l}0.198^{\star * *} \\
(0.010)\end{array}$ \\
\hline Y1999 & $\begin{array}{l}0.102^{\star \star \star} \\
(0.023)\end{array}$ & $\begin{array}{l}0.192^{\star \star \star} \\
(0.011)\end{array}$ \\
\hline Y2000 & $\begin{array}{c}0.037 \\
(0.019)\end{array}$ & $\begin{array}{l}0.055^{\star \star \star} \\
(0.012)\end{array}$ \\
\hline Y2001 & $\begin{array}{c}0.037^{* *} \\
(0.019)\end{array}$ & $\begin{array}{l}0.043^{\star \star \star} \\
(0.012)\end{array}$ \\
\hline Y2002 & $\begin{array}{c}0.029 \\
(0.018)\end{array}$ & $\begin{array}{l}0.041^{\star * *} \\
(0.012)\end{array}$ \\
\hline Y2003 & $\begin{array}{c}0.023 \\
(0.018)\end{array}$ & $\begin{array}{l}0.032^{\star \star} \\
(0.013)\end{array}$ \\
\hline Y2004 & $\begin{array}{c}-0.002 \\
(0.015)\end{array}$ & $\begin{array}{c}0.032^{\star \star} \\
(0.013)\end{array}$ \\
\hline
\end{tabular}


TABLE 3 (continued)

Analysis of Funds' Proximity to the $12 \mathrm{~b}-1$ Fee Cap

\begin{tabular}{|c|c|c|}
\hline Variables & $\begin{array}{c}\text { Load Fund } \\
1\end{array}$ & $\begin{array}{c}\text { No-Load Fund } \\
2 \\
\end{array}$ \\
\hline Y2005 & $\begin{array}{c}-0.000 \\
(0.014)\end{array}$ & $\begin{array}{l}0.025^{* *} \\
(0.012)\end{array}$ \\
\hline Y2006 & $\begin{array}{c}-0.006 \\
(0.013)\end{array}$ & $\begin{array}{l}0.026^{\star \star} \\
(0.011)\end{array}$ \\
\hline Y2007 & $\begin{array}{c}0.015 \\
(0.011)\end{array}$ & $\begin{array}{l}0.024^{\star \star \star} \\
(0.009)\end{array}$ \\
\hline Y2008 & $\begin{array}{l}0.039^{* * *} \\
(0.010)\end{array}$ & $\begin{array}{l}0.023^{* \star *} \\
(0.008)\end{array}$ \\
\hline Y2009 & $\begin{array}{l}0.025^{\star \star} \\
(0.010)\end{array}$ & $\begin{array}{l}0.016^{\star \star} \\
(0.007)\end{array}$ \\
\hline Y2010 & $\begin{array}{c}-0.009 \\
(0.008)\end{array}$ & $\begin{array}{l}0.009^{* *} \\
(0.004)\end{array}$ \\
\hline Y2011 & $\begin{array}{l}-0.008 \\
(0.004)\end{array}$ & $\begin{array}{l}-0.001 \\
(0.003)\end{array}$ \\
\hline Style fixed effects & Yes & Yes \\
\hline $\begin{array}{l}\text { No. of obs. } \\
\text { Adj. } R^{2}\end{array}$ & $\begin{array}{r}313,611 \\
0.168\end{array}$ & $\begin{array}{r}74,644 \\
0.549\end{array}$ \\
\hline
\end{tabular}

fees near or at the cap. The absence of statistical significance on year fixed effects after 2001 confirms the results of our structural break tests.

\section{Performance Persistence}

Our next step toward understanding whether retail investors are being sold poorly performing funds after the structural change in the charging of marketing and distribution expenses is to examine performance persistence before and after 2000. We follow the ranking/evaluation methodology of Carhart (1997), Bollen and Busse (2005), and Elton, Gruber, and Blake (2013) to examine the out-ofsample performance of mutual funds.

Our approach to measuring performance persistence of equity funds follows the ranking/evaluation methodology of Hunter et al. (2014). ${ }^{23}$ At the end of each month, starting on Dec. 31, 1992, and ending on Dec. 31, 2011, we rank all equity funds by the $t$-statistic of the pre-expense alpha from the respective model, measured over the prior 36 months (we require at least 30 months of returns to be nonmissing during this period). ${ }^{24}$ Next, quartile portfolios of funds are formed and equal-weighted portfolio net returns are computed over the following (out-ofsample) year. We then compute the alpha from equations (2) and (3) over this year for equity funds, respectively. We repeat this process over the following month and compute the time-series average alphas and their time-series $t$-statistics over all such (overlapping) out-of-sample years. The standard errors are adjusted for the time-series overlapping nature of the windows over which the alphas are computed.

\footnotetext{
${ }^{23}$ Note that Hunter et al. (2014) include only no-load funds in their analysis to minimize the cost of trading mutual funds to make APB a realistic baseline investment. However, we focus on both load and no-load funds in our out-of-sample performance analysis to take into account the differences in $12 \mathrm{~b}-1$ fee structures in the two fund types.

${ }^{24}$ Kosowski et al. (2006) and Hunter et al. (2014) show that ranking by the alpha $t$-statistic is especially effective in improving the selection of funds with future outperformance.
} 
Since we are interested in examining whether fund managers are able to outperform net of expenses, we utilize net returns in our out-of-sample performance analysis. In Table 4, we find that (net-of-expense) alphas monotonically decrease from quartile 1 (top-ranked funds) to quartile 4 (bottom-ranked funds) for both funds charging 12b-1 fees at and below the cap during the pre- and post-2000 periods. For example, before 2000, top-ranked funds that charged 12b-1 fees at the cap exhibit a monthly Carhart (1997) 4-factor (APB) alpha of 5.1 bps $(61.2$ bps/year), while the second, third, and fourth quartiles exhibit alphas of $-6 \mathrm{bps}$, $-24 \mathrm{bps}$, and $-13 \mathrm{bps}$, respectively.

We do not find any evidence of positive performance persistence for topquartile funds. Instead, we find that top-quartile funds that charge $12 \mathrm{~b}-1$ fees at the cap exhibit negative performance persistence (the results being statistically significant at the $1 \%$ level) after 2000. Such negative performance persistence is not present prior to 2000 or for funds that do not charge $12 \mathrm{~b}-1$ fees at the cap after 2000. These findings are consistent with the already documented agency problems surrounding the practices of charging asset-based marketing and distribution fees at the expense of existing shareholders (Bergstresser et al. (2009), Del Guercio and Reuters (2014)). Our innovation is in showing that these findings are confined to the post-2000 period, indicating support for our first hypothesis that the regulated caps on 12b-1 fees are associated with negative performance persistence.

\section{TABLE 4}

\section{Out-of-Sample Performance as a Function of In-Sample Alpha $t$-Statistics}

\begin{tabular}{|c|c|c|c|c|c|c|}
\hline & & $\mathrm{CAP}=1$ & & & $\mathrm{CAP}=0$ & \\
\hline & All & Pre-2000 & Post-2000 & All & Pre-2000 & Post-2000 \\
\hline & 1 & 2 & 3 & 4 & 5 & 6 \\
\hline 1st Quartile & $\begin{array}{l}-0.090^{\star *} \\
(-1.984)\end{array}$ & $\begin{array}{c}0.051 \\
(-0.607)\end{array}$ & $\begin{array}{l}-0.167^{\star \star \star} \\
(-2.737)\end{array}$ & $\begin{array}{c}-0.052 \\
(-1.003)\end{array}$ & $\begin{array}{c}-0.006 \\
(-0.514)\end{array}$ & $\begin{array}{c}-0.088 \\
(-1.406)\end{array}$ \\
\hline 2nd Quartile & $\begin{array}{l}-0.140^{\star \star *} \\
(-3.170)\end{array}$ & $\begin{array}{c}-0.060 \\
(-0.879)\end{array}$ & $\begin{array}{l}-0.174^{\star \star \star} \\
(-4.327)\end{array}$ & $\begin{array}{l}-0.102^{\star \star *} \\
(-2.923)\end{array}$ & $\begin{array}{c}-0.037 \\
(-0.702)\end{array}$ & $\begin{array}{l}-0.135^{\star \star \star} \\
(-4.102)\end{array}$ \\
\hline 3rd Quartile & $\begin{array}{l}-0.208^{* * *} \\
(-3.615)\end{array}$ & $\begin{array}{l}-0.240^{\star \star} \\
(-2.242)\end{array}$ & 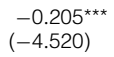 & $\begin{array}{l}-0.125^{\text {***}} \\
(-3.535)\end{array}$ & $\begin{array}{c}-0.098 \\
(-1.832)\end{array}$ & $\begin{array}{l}-0.156^{\star \star \star} \\
(-4.707)\end{array}$ \\
\hline 4th Quartile & $\begin{array}{l}-0.174^{\star \star \star} \\
(-2.836)\end{array}$ & $\begin{array}{c}-0.131 \\
(-1.231)\end{array}$ & $\begin{array}{l}-0.215^{\text {} \star \star \star ~} \\
(-3.851)\end{array}$ & $\begin{array}{l}-0.140^{\star \star \star} \\
(-2.675)\end{array}$ & $\begin{array}{c}-0.100 \\
(-1.826)\end{array}$ & $\begin{array}{l}-0.173^{\star \star \star} \\
(-3.324)\end{array}$ \\
\hline 1st-4th Quartile & $\begin{array}{c}0.084 \\
(0.628)\end{array}$ & $\begin{array}{c}0.183 \\
(0.730)\end{array}$ & $\begin{array}{c}0.047 \\
(0.653)\end{array}$ & $\begin{array}{c}0.088 \\
(0.960)\end{array}$ & $\begin{array}{c}0.093 \\
(0.733) \\
\end{array}$ & $\begin{array}{c}0.085 \\
(1.114) \\
\end{array}$ \\
\hline
\end{tabular}

\section{E. Relationship between 12b-1 Fees and Fund Performance}

Next, we turn to the relationship between charging $12 \mathrm{~b}-1$ fees at the regulated cap and future fund performance. To address this issue, we introduce both the CAP and 12B-1_FEE variables in the following regression specification, implemented before and after the 2000 structural break: 


$$
\begin{aligned}
& \text { FUND_ALPHA }_{i, t+1: t+12}=\beta_{0}+\beta_{1} \ln (\mathrm{SIZE})_{i, t}+\beta_{2} \ln (\mathrm{AGE})_{i, t}
\end{aligned}
$$

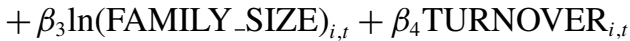

$$
\begin{aligned}
& +\beta_{5} \text { FUND_REVENUE }_{i, t}+\beta_{6} \text { FAMILY_REVENUE }_{i, t} \\
& +\beta_{7} \text { HERFINDAHL }_{i, t}+\beta_{8} \text { VOLATILITY }_{i, t} \\
& +\beta_{9} \text { FUND_FLOW }_{i, t}+\beta_{10} \text { FUND_ALPHA }_{i, t} \\
& +\beta_{11} \mathrm{CAP}_{-} 12 \mathrm{~B}-1 \_\mathrm{FEE}_{i, t}+\varepsilon_{i, t} \text {. }
\end{aligned}
$$

The regressors used in equation (5) are described in the Appendix, and FUND_ALPHA is measured based on Carhart's (1997) 4-factor model and APB,

\begin{tabular}{|c|c|c|c|c|c|c|}
\hline & All & $r$ re- 2000 & rust-zovo & All & rie-<000 & Post-2000 \\
\hline Variables & 1 & 2 & 3 & 4 & 5 & 6 \\
\hline Intercept & $\begin{array}{c}-0.143 \\
(0.609)\end{array}$ & $\begin{array}{c}1.239 \\
(1.057)\end{array}$ & $\begin{array}{l}-2.389 \\
(1.377)\end{array}$ & $\begin{array}{c}-2.743^{\star * *} \\
(0.591)\end{array}$ & $\begin{array}{l}2.368^{\star \star} \\
(1.021)\end{array}$ & $\begin{array}{c}0.768 \\
(5.121)\end{array}$ \\
\hline $\ln (\mathrm{SIZE})$ & $\begin{array}{l}-0.112^{* * \star} \\
(0.021)\end{array}$ & $\begin{array}{c}-0.161^{\star *} \\
(0.078)\end{array}$ & $\begin{array}{l}-0.112^{\star * *} \\
(0.021)\end{array}$ & $\begin{array}{c}-0.127^{\star \star *} \\
(0.022)\end{array}$ & $\begin{array}{c}-0.160^{\star *} \\
(0.077)\end{array}$ & $\begin{array}{c}-0.127^{\star \star \star} \\
(0.022)\end{array}$ \\
\hline $\ln (A G E)$ & $\begin{array}{l}0.221^{* * *} \\
(0.038)\end{array}$ & $\begin{array}{l}0.178^{* *} \\
(0.084)\end{array}$ & $\begin{array}{l}0.246^{* * *} \\
(0.046)\end{array}$ & $\begin{array}{l}0.221^{* * *} \\
(0.041)\end{array}$ & $\begin{array}{c}0.161 \\
(0.085)\end{array}$ & $\begin{array}{l}0.233^{* * *} \\
(0.051)\end{array}$ \\
\hline In(FAMILY_SIZE) & $\begin{array}{c}0.034 \\
(0.019)\end{array}$ & $\begin{array}{c}0.061 \\
(0.054)\end{array}$ & $\begin{array}{c}0.024 \\
(0.020)\end{array}$ & $\begin{array}{l}0.057^{\star *} \\
(0.022)\end{array}$ & $\begin{array}{l}0.066 \\
(0.055)\end{array}$ & $\begin{array}{l}0.053^{\star \star} \\
(0.023)\end{array}$ \\
\hline TURNOVER & $\begin{array}{l}-0.158^{* * *} \\
(0.050)\end{array}$ & $\begin{array}{c}0.132 \\
(0.137)\end{array}$ & $\begin{array}{l}-0.219^{* * *} \\
(0.058)\end{array}$ & $\begin{array}{l}-0.189^{* * *} \\
(0.055)\end{array}$ & $\begin{array}{c}0.131 \\
(0.139)\end{array}$ & $\begin{array}{c}-0.259^{\star * * *} \\
(0.064)\end{array}$ \\
\hline FUND_REVENUE & $\begin{array}{l}0.097 \\
(0.056)\end{array}$ & $\begin{array}{c}0.190 \\
(0.170)\end{array}$ & $\begin{array}{c}-0.049 \\
(0.057)\end{array}$ & $\begin{array}{c}0.12 \\
(0.068)\end{array}$ & $\begin{array}{c}0.186 \\
(0.209)\end{array}$ & $\begin{array}{c}-0.024 \\
(0.066)\end{array}$ \\
\hline FAMILY_REVENUE & $\begin{array}{c}0.002 \\
(0.001)\end{array}$ & $\begin{array}{l}0.008 \\
(0.009)\end{array}$ & $\begin{array}{l}0.003^{* *} \\
(0.001)\end{array}$ & $\begin{array}{c}0.002 \\
(0.001)\end{array}$ & $\begin{array}{l}0.007 \\
(0.009)\end{array}$ & $\begin{array}{c}0.002 \\
(0.002)\end{array}$ \\
\hline HERFINDAHL & $\begin{array}{l}0.268 \\
(0.158)\end{array}$ & $\begin{array}{c}-0.846^{* * *} \\
(0.310)\end{array}$ & $\begin{array}{l}0.452^{* \star} \\
(0.181)\end{array}$ & $\begin{array}{c}0.010 \\
(0.161)\end{array}$ & $\begin{array}{l}-0.898^{\star \star *} \\
(0.312)\end{array}$ & $\begin{array}{c}0.132 \\
(0.182)\end{array}$ \\
\hline VOLATILITY & $\begin{array}{l}-0.059^{\star * *} \\
(0.021)\end{array}$ & $\begin{array}{c}-0.186^{* * *} \\
(0.061)\end{array}$ & $\begin{array}{l}-0.094^{* \star *} \\
(0.024)\end{array}$ & $\begin{array}{c}-0.046^{\star *} \\
(0.021)\end{array}$ & $\begin{array}{l}-0.197^{\star \star *} \\
(0.060)\end{array}$ & $\begin{array}{c}-0.076^{\star * \star} \\
(0.024)\end{array}$ \\
\hline FUND_FLOW & $\begin{array}{l}0.851^{* * *} \\
(0.078)\end{array}$ & $\begin{array}{l}0.863^{* * *} \\
(0.149)\end{array}$ & $\begin{array}{l}0.793^{* * *} \\
(0.091)\end{array}$ & $\begin{array}{l}0.902^{* * *} \\
(0.093)\end{array}$ & $\begin{array}{l}0.867^{\star * *} \\
(0.151)\end{array}$ & $\begin{array}{l}0.837^{\star * *} \\
(0.114)\end{array}$ \\
\hline FUND_ALPHA & $\begin{array}{l}0.629^{* * *} \\
(0.010)\end{array}$ & $\begin{array}{l}0.702^{* * *} \\
(0.028)\end{array}$ & $\begin{array}{l}0.603^{* * *} \\
(0.010)\end{array}$ & $\begin{array}{l}0.622^{* * *} \\
(0.011)\end{array}$ & $\begin{array}{l}0.694^{* * *} \\
(0.029)\end{array}$ & $\begin{array}{l}0.595^{\star * *} \\
(0.011)\end{array}$ \\
\hline CAP & $\begin{array}{l}-0.142^{* * *} \\
(0.043)\end{array}$ & $\begin{array}{c}0.121 \\
(0.179)\end{array}$ & $\begin{array}{l}-0.193^{* * *} \\
(0.045)\end{array}$ & & & \\
\hline 12B-1_FEE & & & & $\begin{array}{l}-0.287^{\star * *} \\
(0.077)\end{array}$ & $\begin{array}{l}-0.147 \\
(0.240)\end{array}$ & $\begin{array}{l}-0.343^{\star * *} \\
(0.075)\end{array}$ \\
\hline $\begin{array}{l}\text { Style fixed effects } \\
\text { Time fixed effects }\end{array}$ & $\begin{array}{l}\text { Yes } \\
\text { Yes }\end{array}$ & $\begin{array}{l}\text { Yes } \\
\text { Yes }\end{array}$ & $\begin{array}{l}\text { Yes } \\
\text { Yes }\end{array}$ & $\begin{array}{l}\text { Yes } \\
\text { Yes }\end{array}$ & $\begin{array}{l}\text { Yes } \\
\text { Yes }\end{array}$ & $\begin{array}{l}\text { Yes } \\
\text { Yes }\end{array}$ \\
\hline $\begin{array}{l}\text { No. of obs. } \\
\text { Adj. } R^{2}\end{array}$ & $\begin{array}{r}236,714 \\
0.525\end{array}$ & $\begin{array}{r}33,488 \\
0.452\end{array}$ & $\begin{array}{r}195,140 \\
0.529\end{array}$ & $\begin{array}{r}203,784 \\
0.522\end{array}$ & $\begin{array}{r}33,141 \\
0.450\end{array}$ & $\begin{array}{r}163,779 \\
0.529\end{array}$ \\
\hline
\end{tabular}
as proposed by Hunter et al. (2014). In model 3 of Table 5, we find a significant

\section{TABLE 5}

\section{Impact of Setting 12b-1 Fees at the Cap on Fund Performance}


negative relationship between charging $12 \mathrm{~b}-1$ fees at the cap and future riskadjusted returns during the post-2000 period. Such findings, however, are not observable during the pre-2000 era. To interpret the economic magnitude of this result, in model 3 of Table 5, the regression coefficient of -0.193 for the CAP indicator variable represents a decrease of 19.3 bps per year in the subsequent fund risk-adjusted return for funds that charge $12 \mathrm{~b}-1$ fees at the cap. When we repeat the empirical tests by replacing CAP with the continuous variable 12B-1_FEE, the results in models 5 and 6 are qualitatively similar.

These findings are consistent with our first hypothesis that the negative effects of skewed broker incentives occur after the structural shift in the charging of marketing and distribution expenses. Funds that charge higher $12 \mathrm{~b}-1$ fees suffer in terms of lower risk-adjusted performance. Our findings for the post-2000 period are consistent with previous studies that regard $12 \mathrm{~b}-1$ fees as deadweight costs, which contradict regulators' original justification of raising fees to grow AUM and, in the process, achieve economies of scale and better overall performance (e.g., Ferris and Chance (1987, 1991), Freeman and Brown (2001), Dukes et al. (2006), and Bergstresser et al. (2009)).

\section{F. Impact of Regulated Caps on Client Information and Choices}

How fund flows behave once the industry shifts to charging 12b-1 fees toward the regulated cap informs us about whether caps on fund brokerage fees have the unintended consequences predicted by theory and our second hypothesis. To address this issue, we create a FUND_FLOW variable following Sirri and Tufano (1998), with fund flows estimated as

$$
\text { FUND_FLOW }_{i, t}=\frac{\mathrm{TNA}_{i, t}-\mathrm{TNA}_{i, t-1} \times\left(1+R_{i, t}\right)}{\mathrm{TNA}_{i, t-1}},
$$

where FUND_FLOW ${ }_{i, t}$ measures the percentage growth of a fund $i$ that is due to new investments, TNA $_{i, t}$ is the fund's total net assets, and $R_{i, t}$ is the fund's return over the prior quarter.

We utilize the framework of Huang et al. (2007) to examine the impact of the shift in the 12b-1 fee-setting regime on the flow-performance relationship. This setting allows us to identify where along the past fund performance spectrum (low, medium, or high) we find the most flow-performance sensitivity. Using data from 1981 to 2001, Huang et al. (2007) find that flows are more (less) responsive to the medium (high) fund performance range, explaining the convex flow-performance relationship shown by Sirri and Tufano (1998). In each quarter, we rank all funds according to their Carhart (1997) 4-factor (APB) alphas and assign them a continuous rank ranging from 0 (worst) to 1 (best). After classifying funds into low-, medium-, and high-performance groups based on their performance percentiles in the same investment objective category, we interact performance rank with marketing and distribution fees in the following regression model:

$$
\begin{aligned}
\text { FUND_FLOW }_{i, t}=\beta_{0}+\beta_{1} \mathrm{LOW}_{i, t-1} \\
\quad+\beta_{2} \mathrm{LOW}_{i, t-1} \times 12 \mathrm{~B}-1 \mathrm{FEE}_{t-1}+\beta_{3} \mathrm{MID}_{i, t-1} \\
+\beta_{4} \mathrm{MID}_{i, t-1} \times 12 \mathrm{~B}-1 \mathrm{FEE}_{t-1} \\
+\beta_{5} \mathrm{HIGH}_{i, t-1}+\beta_{6} \mathrm{HIGH}_{i, t-1} \times 12 \mathrm{~B}-1 \mathrm{FEE}_{t-1} \\
+\beta_{7} \mathrm{Controls}+\varepsilon_{i, t},
\end{aligned}
$$


where $\mathrm{LOW}_{i, t-1}$ represents the performance rank in the lowest quintile and is measured as $\min \left(\mathrm{RANK}_{t}, 0.2\right), \mathrm{MID}_{i, t-1}$ represents the performance rank in quintiles 2-4 and is measured as $\min \left(\mathrm{RANK}_{t}-\mathrm{LOW}, 0.6\right)$, and $\mathrm{HIGH}_{i, t-1}$ represents the performance rank in the highest quintile and is measured as $\min \left(\mathrm{RANK}_{t}-\right.$ LOW - MID, 0.2).

We report the results of this analysis in Table 6 . We use 4 proxies of mutual fund brokerage fees. In Panel A, we incorporate the indicator variable CAP (columns 1-3) as well as the continuous measure 12B-1_FEE (columns 4-6). In Panel B, to facilitate direct comparison with the results of Huang et al. (2007), we

\title{
TABLE 6
}

Impact of Setting 12b-1 Fees at the Cap on Money Flows

\begin{abstract}
Table 6 provides the regression results of the impact of setting $12 \mathrm{~b}-1$ fees at the cap on subsequent money flows. The dependent variable is FUND_FLOW, which measures the percentage growth of a fund that is due to new investments, following Sirri and Tufano (1998). Independent variables include the following: CATEGORY_FLOW is the aggregate flow into each fund category in quarter $t$; VOLATILITY is the standard deviation of a fund's net returns over the past 12 months; In(AGE) is the natural logarithm of fund age; In(SIZE) is the natural logarithm of fund size in the previous quarter; EXPENSE_RATIO is the ratio of the fund's operating expense over total net assets; CAP is a dummy variable equal to 1 if funds charge $12 \mathrm{~b}-1$ fees at the regulated cap ( $1 \%$ for load funds and $0.25 \%$ for no-load funds), and 0 otherwise; 12B-1_FEE is the fee paid for the marketing and distribution of funds; DISTRIBUTION_FEE is $12 \mathrm{~b}-1$ fees plus one-seventh of front-end loads: TOTAL FEE is the expense ratio plus one-seventh of front-end loads; LOW formance rank in the lowest quintile and is measured as $\min \left(\mathrm{RANK}_{t}, 0.2\right) ; \mathrm{MID}_{i, t-1}$ represents the performance rank in quintiles 2-4 and is measured as min(RANK $\left.{ }_{t}-\mathrm{LOW}, 0.6\right)$; and $\mathrm{HIGH}_{i, t-1}$ represents the performance rank in the highest quintile and is measured as $\min \left(\mathrm{RANK}_{t}-\mathrm{LOW}-\mathrm{MID}, 0.2\right)$. The time-series average coefficients and Fama-MacBeth (1973) $t$-statistics (in parentheses), calculated with Newey-West (1987) robust standard errors, are reported. ${ }^{* *}$ and ${ }^{* * \star}$ indicate significance at the $5 \%$ and $1 \%$ levels, respectively.
\end{abstract}

Panel A. 12b-1 Fees as Brokerage Fee Proxy

\begin{tabular}{|c|c|c|c|c|c|c|}
\hline \multirow{3}{*}{ Variables } & \multicolumn{3}{|c|}{ CAP } & \multicolumn{3}{|c|}{ 12B-1_FEE } \\
\hline & All & Pre-2000 & Post-2000 & All & Pre-2000 & Post-2000 \\
\hline & 1 & 2 & 3 & 4 & 5 & 6 \\
\hline Intercept & $\begin{array}{c}0.130 \\
(0.106)\end{array}$ & $\begin{array}{l}-2.211 \\
(-1.065)\end{array}$ & $\begin{array}{c}1.938 \\
(1.544)\end{array}$ & $\begin{array}{c}0.338 \\
(0.274)\end{array}$ & $\begin{array}{c}-1.168 \\
(-0.591)\end{array}$ & $\begin{array}{c}1.521 \\
(0.986)\end{array}$ \\
\hline CATEGORY_FLOW & $\begin{array}{l}0.086^{\star \star} \\
(2.336)\end{array}$ & $\begin{array}{c}-0.024 \\
(-0.295)\end{array}$ & 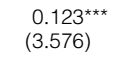 & $\begin{array}{l}0.075^{\star \star} \\
(2.215)\end{array}$ & $\begin{array}{c}-0.025 \\
(-0.303)\end{array}$ & $\begin{array}{l}0.109^{\star \star \star} \\
(3.806)\end{array}$ \\
\hline VOLATILITY & $\begin{array}{c}0.042 \\
(0.231)\end{array}$ & $\begin{array}{c}0.559 \\
(1.219)\end{array}$ & $\begin{array}{l}-0.247^{\star *} \\
(-2.145)\end{array}$ & $\begin{array}{c}0.019 \\
(0.098)\end{array}$ & $\begin{array}{c}0.640 \\
(1.362)\end{array}$ & $\begin{array}{l}-0.324^{\star \star \star} \\
(-3.064)\end{array}$ \\
\hline $\ln (A G E)$ & $\begin{array}{c}-1.414^{\star \star \star} \\
(-11.276)\end{array}$ & $\begin{array}{c}-1.094^{* * *} \\
(-11.137)\end{array}$ & $\begin{array}{l}-1.512^{\star \star \star} \\
(-8.674)\end{array}$ & $\begin{array}{c}-1.486^{\star \star *} \\
(-12.412)\end{array}$ & $\begin{array}{l}-1.059^{\star \star \star} \\
(-9.786)\end{array}$ & $\begin{array}{c}-1.620^{\star \star \star} \\
(-10.423)\end{array}$ \\
\hline In(AGE) $\times$ FUND_ALPHA & $\begin{array}{l}0.502^{\star \star} \\
(2.292)\end{array}$ & $\begin{array}{l}1.301^{\text {***}} \\
(3.436)\end{array}$ & $\begin{array}{c}0.190 \\
(0.799)\end{array}$ & $\begin{array}{c}0.467 \\
(1.591)\end{array}$ & $\begin{array}{l}1.438^{\star \star \star} \\
(2.989)\end{array}$ & $\begin{array}{c}0.057 \\
(0.169)\end{array}$ \\
\hline $\ln (\mathrm{SIZE})$ & $\begin{array}{c}0.073 \\
(1.807)\end{array}$ & $\begin{array}{c}0.058 \\
(0.931)\end{array}$ & $\begin{array}{c}0.044 \\
(0.922)\end{array}$ & $\begin{array}{l}0.084^{\star *} \\
(2.187)\end{array}$ & $\begin{array}{c}-0.002 \\
(-0.032)\end{array}$ & $\begin{array}{l}0.101^{\star \star} \\
(2.250)\end{array}$ \\
\hline EXPENSE_RATIO & $\begin{array}{l}-1.115^{\star \star \star} \\
(-4.709)\end{array}$ & $\begin{array}{c}-0.016 \\
(-0.095)\end{array}$ & $\begin{array}{l}-1.623^{\star \star *} \\
(-6.687)\end{array}$ & $\begin{array}{l}-0.707^{\star \star \star} \\
(-2.895)\end{array}$ & $\begin{array}{l}-0.677^{* *} \\
(-2.178)\end{array}$ & $\begin{array}{c}-0.556 \\
(-1.827)\end{array}$ \\
\hline MARKETING_EXPENSE & $\begin{array}{c}-0.413 \\
(-1.782)\end{array}$ & $\begin{array}{c}0.287 \\
(0.592)\end{array}$ & $\begin{array}{l}-0.746^{\star \star *} \\
(-3.245)\end{array}$ & 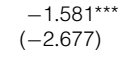 & $\begin{array}{c}0.077 \\
(0.103)\end{array}$ & $\begin{array}{l}-2.581^{\star \star \star} \\
(-3.690)\end{array}$ \\
\hline LOW & $\begin{array}{l}11.095^{\star \star \star} \\
(6.290)\end{array}$ & $\begin{array}{l}8.955^{\star \star \star} \\
(3.111)\end{array}$ & $\begin{array}{l}11.210^{* * *} \\
(4.851)\end{array}$ & $\begin{array}{l}12.748^{\star \star \star} \\
(4.884)\end{array}$ & $\begin{array}{l}6.902^{\star \star} \\
(2.129)\end{array}$ & $\begin{array}{l}14.468^{\star \star \star} \\
(4.039)\end{array}$ \\
\hline LOW $\times$ MARKETING_EXPENSE & $\begin{array}{l}-2.865^{\star \star} \\
(-2.397)\end{array}$ & $\begin{array}{l}-2.195 \\
(-0.702)\end{array}$ & $\begin{array}{r}-2.932^{*} \\
(-2.656)\end{array}$ & $\begin{array}{c}-2.137 \\
(-0.916)\end{array}$ & $\begin{array}{c}3.705 \\
(0.834)\end{array}$ & $\begin{array}{c}-4.275 \\
(-1.575)\end{array}$ \\
\hline MID & $\begin{array}{c}4.626^{\star \star \star} \\
(12.457)\end{array}$ & $\begin{array}{l}4.442^{\star \star \star} \\
(9.373)\end{array}$ & $\begin{array}{l}4.576^{\star \star *} \\
(8.806)\end{array}$ & $\begin{array}{l}4.019^{\star \star \star} \\
(6.435)\end{array}$ & $\begin{array}{l}3.582^{\star \star \star} \\
(4.080)\end{array}$ & $\begin{array}{l}4.166^{\star \star \star} \\
(4.729)\end{array}$ \\
\hline MID $\times$ MARKETING_EXPENSE & $\begin{array}{l}1.359^{\star \star} \\
(2.408)\end{array}$ & $\begin{array}{l}3.000^{* *} \\
(2.638)\end{array}$ & $\begin{array}{c}0.283 \\
(0.764)\end{array}$ & $\begin{array}{l}2.021^{\star *} \\
(2.469)\end{array}$ & $\begin{array}{l}4.504^{\star \star \star} \\
(3.433)\end{array}$ & $\begin{array}{c}0.635 \\
(0.785)\end{array}$ \\
\hline $\mathrm{HIGH}$ & $\begin{array}{l}29.985^{\star \star \star} \\
(12.867)\end{array}$ & $\begin{array}{l}20.927^{\star \star \star} \\
(4.814)\end{array}$ & $\begin{array}{l}33.787^{\star \star *} \\
(15.842)\end{array}$ & $\begin{array}{l}31.966^{\star \star \star} \\
(12.737)\end{array}$ & $\begin{array}{l}25.620^{* \star \star} \\
(5.538)\end{array}$ & $\begin{array}{l}35.125^{\star \star \star} \\
(12.686)\end{array}$ \\
\hline $\mathrm{HIGH} \times$ MARKETING_EXPENSE & $\begin{array}{c}-2.224 \\
(-0.620)\end{array}$ & $\begin{array}{c}8.962 \\
(0.976)\end{array}$ & $\begin{array}{l}-7.820^{\star * *} \\
(-3.264)\end{array}$ & $\begin{array}{l}-13.746^{\star \star \star} \\
(-3.636)\end{array}$ & $\begin{array}{l}-26.663^{\star \star \star} \\
(-3.769)\end{array}$ & $\begin{array}{l}-10.567^{\star \star \star} \\
(-3.034)\end{array}$ \\
\hline
\end{tabular}


TABLE 6 (continued)

Impact of Setting 12b-1 Fees at the Cap on Money Flows

Panel B. Huang et al. Marketing Expense Proxies

\begin{tabular}{|c|c|c|c|c|c|c|}
\hline \multirow{3}{*}{ Variables } & \multicolumn{3}{|c|}{ DISTRIBUTION_FEE } & \multicolumn{3}{|c|}{ TOTAL_FEE } \\
\hline & All & Pre-2000 & Post-2000 & All & Pre-2000 & Post-2000 \\
\hline & 1 & 2 & 3 & 4 & 5 & 6 \\
\hline MARKETING_EXPENSE & $\begin{array}{l}-0.016^{\star \star \star} \\
(-2.663)\end{array}$ & $\begin{array}{c}0.001 \\
(0.112)\end{array}$ & $\begin{array}{l}-0.026^{\star \star \star} \\
(-3.678)\end{array}$ & $\begin{array}{c}-0.002 \\
(-1.051)\end{array}$ & $\begin{array}{c}0.000 \\
(0.023)\end{array}$ & $\begin{array}{c}-0.003 \\
(-1.435)\end{array}$ \\
\hline LOW & $\begin{array}{l}12.761^{\star \star \star} \\
(4.872)\end{array}$ & $\begin{array}{l}6.895^{\star *} \\
(2.123)\end{array}$ & $\begin{array}{l}14.488^{* \star *} \\
(4.030)\end{array}$ & 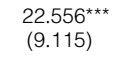 & $\begin{array}{l}13.345^{\star \star \star} \\
(3.779)\end{array}$ & $\begin{array}{c}26.498^{\star \star \star} \\
(9.667)\end{array}$ \\
\hline LOW $\times$ MARKETING_EXPENSE & $\begin{array}{l}-0.021 \\
(-0.916)\end{array}$ & $\begin{array}{c}0.037 \\
(0.840)\end{array}$ & $\begin{array}{c}-0.043 \\
(-1.576)\end{array}$ & $\begin{array}{l}-0.081^{\star \star \star} \\
(-7.067)\end{array}$ & $\begin{array}{l}-0.046^{\star \star} \\
(-2.209)\end{array}$ & $\begin{array}{l}-0.099^{\star \star \star} \\
(-8.207)\end{array}$ \\
\hline MID & $\begin{array}{l}4.012^{\star \star \star} \\
(6.400)\end{array}$ & $\begin{array}{l}3.578^{\star \star *} \\
(4.060)\end{array}$ & $\begin{array}{l}4.159^{* * *} \\
(4.705)\end{array}$ & $\begin{array}{l}3.239^{\text {*** }} \\
(3.714)\end{array}$ & $\begin{array}{c}-0.446 \\
(-0.362)\end{array}$ & 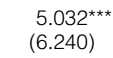 \\
\hline MID $\times$ MARKETING_EXPENSE & $\begin{array}{l}0.020^{\star \star} \\
(2.468)\end{array}$ & $\begin{array}{l}0.045^{\star \star \star} \\
(3.415)\end{array}$ & $\begin{array}{c}0.006 \\
(0.792)\end{array}$ & $\begin{array}{l}0.015^{\star \star} \\
(2.358)\end{array}$ & $\begin{array}{l}0.043^{\text {** }} \\
(5.562)\end{array}$ & $\begin{array}{c}-0.000 \\
(-0.084)\end{array}$ \\
\hline $\mathrm{HIGH}$ & $\begin{array}{l}32.006^{\star \star \star} \\
(12.726)\end{array}$ & $\begin{array}{l}25.713^{* * *} \\
(5.539)\end{array}$ & $\begin{array}{l}35.153^{\text {***}} \\
(12.652)\end{array}$ & 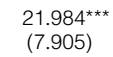 & $\begin{array}{l}14.691^{* *} \\
(2.503)\end{array}$ & $\begin{array}{l}26.095^{\text {} \star \star \star ~} \\
(13.105)\end{array}$ \\
\hline $\mathrm{HIGH} \times$ MARKETING_EXPENSE & 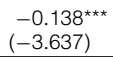 & $\begin{array}{l}-0.269^{* * *} \\
(-3.803)\end{array}$ & $\begin{array}{l}-0.106^{\text {*** }} \\
(-3.024)\end{array}$ & $\begin{array}{l}0.048^{\star *} \\
(2.150)\end{array}$ & $\begin{array}{c}0.054 \\
(1.115)\end{array}$ & $\begin{array}{c}0.037 \\
(1.651)\end{array}$ \\
\hline
\end{tabular}

repeat the analysis using DISTRIBUTION_FEE (12b-1 fees plus one-seventh of front-end loads) and TOTAL_FEE (expense ratio plus one-seventh of front-end loads) as alternative proxies for marketing and distribution efforts.

Consistent with Huang et al. (2007), in results for the full sample reported in column 1 in Panel A of Table 6, we find the coefficient of our interaction term between performance and CAP is significantly positive in the mediumperformance range. This finding suggests that a moderate level of past performance is sufficient to attract investors into the funds, leading to higher flow-performance sensitivity in the medium-performance range. However, after the sample is partitioned into before and after 2000, this finding is restricted to the pre-2000 period. In the post-2000 period, flow-performance sensitivity disappears from the medium-performance range and is largely concentrated in the high-performance range. In addition, with the exception of the proxy of total fees, the coefficient of the interaction term HIGH $\times$ MARKETING_EXPENSE in the post-2000 period is negative and statistically significant. The negative coefficient of the interaction term implies that funds with lower marketing expenses will start to attract investors only as performance improves further in the superior performance range. This evidence is also consistent with the fact that the cap on 12b-1 fees removes the incentive for brokers to learn about any funds other than the highest-performing ones. In other words, by reaching the cap on $12 \mathrm{~b}-1$ fees, mutual fund managers and their brokers face limits on their ability to direct investors to their not-so-visible funds, even those with medium past performance, consistent with our second hypothesis on broker learning incentives. The negative coefficient of the interaction term HIGH $\times$ MARKETING_EXPENSE also points to the likelihood that brokers are resorting to churning fund clients among the high-performance category, possibly in pursuit of revenue.

The evidence in support of our second hypothesis is backed, first, by the competitive maturity of the mutual fund market in the late 1990s (Wahal and Wang (2011)), by which time the regulated cap became too low for the industry. Second, 
2000 is the year Reg FD was introduced, effectively curtailing the preferential access of institutional investors, such as mutual funds, to nonpublic information about equities (Bhojraj et al. (2012)) and, hence, making it difficult for mutual fund brokers to differentiate fund products based on performance. Third, as suggested by theory (Stoughton et al. (2011), Inderst and Ottaviani (2012a)), the increasing segmentation of the mutual fund industry on investor sophistication due to the participation of institutional investors and high-net-worth individuals seems to have exacerbated the skewed incentives of mutual fund brokers who service the majority of retail investors.

\section{Robustness Tests}

\section{A. Time-Series Relationships}

The splitting of our sample based on structural break tests coincides with developments, such as the introduction of Reg FD in 2000, the decimalization of U.S. stock markets between Aug. 2000 and April 2001, and the segmentation of mutual fund styles that peaked during the late 1990s. It may be argued that these confounding events have resulted in structural shifts in marketing and distribution costs that are not picked up by our structural break tests on the main sample. We therefore repeat the tests for structural breaks on various subsamples (load funds, no-load funds, institutional share classes, retail share classes, and funds that cater to both retail and institutional investors) to rule out the alternative explanation that 12b-1 fees may differ across funds targeting heterogeneous clientele groups. Our overall results, not reported here for the sake of brevity but available upon request, show that 2000 is consistently the date of the structural shift in 12b-1 fees toward the regulated cap.

We also take additional steps to address the segmentation of mutual fund styles by using Cremers and Petajisto's (2009) best-fit benchmark to eliminate the bias of having to deal with funds that game their self-designated benchmark or fund categories (as documented by Sensoy (2009)) and the inclusion of style fixed effects to control for unobservable factors that may be driving our results.

\section{B. Retail Share Classes}

Because we include both retail and institutional fund share classes, one may argue that our results could be driven by the differences in distribution fee structures. Following Bergstresser et al. (2009) and Del Guercio and Reuters (2014), we exclude funds sold through institutional channels, given that their sales may be driven by dynamics that differ from those of retail markets. These institutional funds account for approximately one-third of our overall fund share class observations. In unreported results, we repeat all of our empirical tests in Tables 4-6 only on funds sold through retail channels and find qualitatively similar results.

\section{Conclusion}

A scant literature provides empirical evidence that the indirect compensation of mutual fund brokers skews brokers' incentives. Yet the mutual fund brokerage industry, through FINRA and SEC regulations, as well as legislation such as the 
Dodd-Frank Wall Street Reform and Consumer Protection Act, is heavily regulated. Theory predicts that abolishing or capping brokers' compensation may result in unintended consequences, such as the exploitation of naïve retail investors. This paper is the first to examine whether regulated mutual fund marketing and distribution fee caps are associated with skewed broker incentives. We target the long-established regime of regulated caps on $12 \mathrm{~b}-1$ fees, which has existed since 1993. We show that a structural break in the fees occurs in 2000 and is associated with a larger proportion of equity load and no-load funds charging higher 12b-1 fees. The results of our performance persistence tests indicate that it is after the 2000 break point that more negative performance persists in funds that charge $12 \mathrm{~b}-1$ fees at the cap. It is also in the post-2000 period that we find a negative relationship between marketing and distribution expenses and fund performance. Finally, after 2000, we show that flow-performance sensitivity has shifted to the highest-performing funds, suggesting that the fee cap constrains brokers' incentives to learn about low- and medium-ranked funds. Our evidence suggests the churning of investors among high-performing funds, possibly reflecting brokers' pursuit of revenue.

The main policy implication of our paper is that regulators should re-examine the efficacy of imposing caps on indirect sales payments to brokers of financial products. Our findings show that the potentially detrimental effects do not occur immediately after the introduction of the caps. In the mutual fund industry, it took more than 7 years.

Our results also shed light on the puzzle identified by Bergstresser et al. ((2009), p. 4155) of "why investors continue to purchase funds that appear to be no better at substantially higher costs." However, the level of brokerage costs per se is an issue in the presence of caps that preclude brokers and funds from setting fee levels that reflect the cost of properly researching fund products. In relation to this, Wahal and Wang (2011) show that, despite increasing competition, benefits to mutual fund investors have been limited, offering the conjecture that the corresponding rise in distribution costs offsets the gains from competition. The findings of this paper complement the limited literature on mutual fund brokers' incentives by highlighting the role of the unintended consequences of regulation in exacerbating the puzzle of continually exploited retail investors.

Admittedly, by inference, a key assumption of our paper is that the search cost for funds has increased after 2000. If such costs have remained constant, the Inderst and Ottaviani (2012a) theory is not sufficient to explain why the quality of brokered funds has fallen after 2000, as shown by our headline findings. Examining whether fund search costs have increased and modeling falling fund quality in the absence of such a change represent opportunities for future research.

\section{Appendix. Description of Fund Level Variables}

\section{Fund Characteristics}

FUND_SIZE Total AUM at the end of the period. $\ln$ (SIZE) Natural logarithm of total AUM at the end of the period. FUND_AGE Number of years since the fund's inception.

$\ln$ (AGE) Natural logarithm of the number of years since the fund's inception. 
FAMILY_SIZE Aggregate total net assets at the fund management company level.

$\ln$ (FAMILY_SIZE) Natural logarithm of aggregate total net assets at the fund management company level.

TURNOVER Portfolio turnover (minimum of aggregate securities sales or purchases divided by average total net assets) of the fund.

HERFINDAHL Measure of the U.S. mutual fund industry concentration, calculated by summing the squared market shares of the top 50 largest fund families on a monthly basis.

VOLATILITY Measured by the standard deviation of a fund's returns over the past 12 months.

FUND_FLOW Measure of the percentage growth of a fund that is due to new investments, following Sirri and Tufano (1998).

FUND_REVENUE Measure of fund revenue, calculated by multiplying the expense ratio by AUM at the share class level.

FAMILY_REVENUE Measure of family revenue, calculated by aggregating all fund revenues at the share class level to the fund management company level.

CAP Binary variable that equals 1 if the fund charged 12b-1 fees at the regulatory ceiling ( $1 \%$ for load funds and $0.25 \%$ for no-load funds), and 0 otherwise.

12B-1_GAP Difference between the $12 \mathrm{~b}-1$ fee regulatory ceiling and the actual $12 \mathrm{~b}-1$ fee charged by load and no-load funds, expressed in terms of a percentage.

LOAD Binary variable that equals 1 if funds are charging either front-end or rear-end load charges or $12 \mathrm{~b}-1$ fees greater than $0.25 \%$, and 0 otherwise.

\section{Fund Fees}

12B-1_FEE Fee paid for the marketing and distribution of funds.

NON_12B-1_FEE Calculated by subtracting the 12b-1 fee from the expense ratio, following Barber et al. (2005).

MANAGEMENT_FEE Fee paid out of fund assets to the fund's investment adviser.

EXPENSE_RATIO Ratio of the fund's operating expense over total net assets.

TOTAL_FEE Expense ratio plus one-seventh of the total load.

\section{Fund Returns}

GROSS_RETURN Fund's monthly net return plus one-12th of the most recently reported annual expense ratio.

NET_RETURN Fund's monthly return net of operating expenses.

FUND_ALPHA Monthly fund returns adjusted using the 4-factor model and an APB, as proposed by Hunter et al. (2014).

\section{References}

Barber, B. M.; T. Odean; and L. Zheng. "Out of Sight, Out of Mind: The Effects of Expenses on Mutual Fund Flows.” Journal of Business, 78 (2005), 2095-2120.

Bergstresser, D.; J. M. R. Chalmers; and P. Tufano. "Assessing the Costs and Benefits of Brokers in the Mutual Fund Industry.” Review of Financial Studies, 22 (2009), 4129-4156.

Berzins, J.; C. H. Liu; and C. Trzcinka. "Asset Management and Investment Banking." Journal of Financial Economics, 110 (2013), 215-231.

Bhojraj, S.; Y. J. Cho; and N. Yehuda. "Mutual Fund Family Size and Mutual Fund Performance: The Role of Regulatory Changes." Journal of Accounting Research, 50 (2012), 647-684.

Bollen, N. P. B., and J. A. Busse. "Short-Term Persistence in Mutual Fund Performance." Review of Financial Studies, 18 (2005), 569-597.

Carhart, M. M. “On Persistence in Mutual Fund Performance.” Journal of Finance, 52 (1997), 57-82. 
Chen, J.; H. Hong; M. Huang; and J. D. Kubik. "Does Fund Size Erode Mutual Fund Performance? The Role of Liquidity and Organization.” American Economic Review, 94 (2004), 1276-1302.

Christoffersen, S. E. K.; R. Evans; and D. K. Musto. "What Do Consumers' Fund Flows Maximize? Evidence from Their Brokers' Incentives.” Journal of Finance, 68 (2013), 201-235.

Chow, G. C. "Tests of Equality Between Sets of Coefficients in Two Linear Regressions." Econometrica, 28 (1960), 591-605.

Cremers, K. J. M., and A. Petajisto. "How Active Is Your Fund Manager? A New Measure That Predicts Performance." Review of Financial Studies, 22 (2009), 3329-3365.

Del Guercio, D., and J. Reuters. "Mutual Fund Performance and the Incentive to Generate Alpha." Journal of Finance, 69 (2014), 1673-1704.

Dukes, W. P.; P. C. English II; and S. M. Davis. "Mutual Fund Mortality, 12B-1 Fees, and the Net Expense Ratio.” Journal of Financial Research, 29 (2006), 235-252.

Elton, E. J.; M. J. Gruber; and C. R. Blake. "A First Look at the Accuracy of the CRSP Mutual Fund Database and a Comparison of the CRSP and Morningstar Mutual Fund Databases." Journal of Finance, 56 (2001), 2415-2450.

Elton, E. J.; M. J. Gruber; and C. R. Blake. "Does Mutual Fund Size Matter? The Relationship between Size and Performance." Review of Asset Pricing Studies, 2 (2013), 31-55.

Evans, R. B. "Mutual Fund Incubation.” Journal of Finance, 65 (2010), 1581-1611.

Evans, R. B., and R. Fahlenbrach. "Institutional Investors and Mutual Fund Governance: Evidence from Retail-Institutional Fund Twins.” Review of Financial Studies, 25 (2012), 3530-3571.

Fama, E. F., and K. R. French. "Luck versus Skill in the Cross-Section of Mutual Fund Returns." Journal of Finance, 65 (2010), 1915-1947.

Fama, E. F., and J. MacBeth. "Risk, Return, and Equilibrium: Empirical Tests." Journal of Political Economy, 81 (1973), 607-636.

Ferris, S. P., and D. M. Chance. "The Effect of 12B-1 Plans on Mutual Fund Expense Ratios: A Note." Journal of Finance, 42 (1987), 1077-1082.

Ferris, S. P., and D. M. Chance. "Mutual Fund Distribution Fees: An Empirical Analysis of the Impact of Deregulation.” Journal of Financial Services Research, 5 (1991), 25-42.

Ferson, W. E., and R. W. Schadt. "Measuring Fund Strategy and Performance in Changing Economic Conditions." Journal of Finance, 51 (1996), 425-461.

Financial Services Authority. "Product Intervention.” Discussion Paper DP11-1 (2011), 1-61.

Freeman, J. P., and S. L. Brown. "Mutual Fund Advisory Fees: The Cost of Conflicts of Interest." Journal of Corporation Law, 26 (2001), 609-673.

Geranio, M., and G. Zanotti. "Can Mutual Funds Characteristics Explain Fees?” Journal of Multinational Financial Management, 15 (2005), 354-376.

Gruber, M. J. “Another Puzzle: The Growth in Actively Managed Mutual Funds.” Journal of Finance, 51 (1996), 783-810.

Huang, J.; K. D. Wei; and H. Yan. "Participation Costs and the Sensitivity of Fund Flows to Past Performance.” Journal of Finance, 62 (2007), 1273-1311.

Hunter, D.; E. Kandel; S. Kandel; and R. Wermers. "Mutual Fund Performance Evaluation with Active Peer Benchmarks.” Journal of Financial Economics, 112 (2014), 1-29.

Inderst, R., and M. Ottaviani. "Misselling through Agents.” American Economic Review, 99 (2009), 883-908.

Inderst, R., and M. Ottaviani. "Competition through Commissions and Kickbacks." American Economic Review, 102 (2012a), 780-809.

Inderst, R., and M. Ottaviani. "How (Not) to Pay for Advice: A Framework for Consumer Financial Protection.” Journal of Financial Economics, 105 (2012b), 393-411.

Investment Company Institute. Investment Company Fact Book. Washington, DC: Investment Company Institute (2011).

Investment Company Institute. Investment Company Fact Book. Washington, DC: Investment Company Institute (2013).

Knittel, C. R., and V. Stango. "Price Ceilings as Focal Points for Tacit Collusion: Evidence from Credit Cards." American Economic Review, 93 (2003), 1703-1729.

Kosowski, R.; A. Timmermann; R. Wermers; and H. White. "Can Mutual Fund 'Stars' Really Pick Stocks? New Evidence from a Bootstrap Analysis.” Journal of Finance, 61 (2006), 2551-2595.

LaPlante, M. "Influences and Trends in Mutual Fund Expense Ratios." Journal of Financial Research, 24 (2001), 45-63.

Mahoney, P. G. "Manager-Investor Conflicts in Mutual Funds." Journal of Economic Perspectives, 18 (2004), 161-182.

Malhotra, D. K., and R. W. McLeod. “An Empirical Analysis of Mutual Fund Expenses.” Journal of Financial Research, 20 (1997), 175-190. 
Newey, W. K., and K. D. West. "A Simple, Positive Semi-Definite, Heteroskedasticity and Autocorrelation Consistent Covariance Matrix." Econometrica, 55 (1987), 703-708.

Quandt, R. E. "Tests of the Hypothesis That a Linear Regression System Obeys Two Separate Regimes." Journal of the American Statistical Association, 55 (1960), 324-330.

Sensoy, B. A. "Performance Evaluation and Self-Designated Benchmark Indexes in the Mutual Fund Industry." Journal of Financial Economics, 92 (2009), 25-39.

Sirri, E. R., and P. Tufano. "Costly Search and Mutual Fund Flows." Journal of Finance, 53 (1998), $1589-1622$.

Stoughton, N. M.; Y. Wu; and J. Zechner. "Intermediated Investment Management." Journal of Finance, 66 (2011), 947-980.

Tufano, P., and M. Sevick. "Board Structure and Fee-Setting in the U.S. Mutual Fund Industry." Journal of Financial Economics, 46 (1997), 321-355.

Wahal, S., and A. Y. Wang. "Competition among Mutual Funds." Journal of Financial Economics, 99 (2011), 40-59. 